\title{
PEPPERDINE
}

UNIVERSITY — Pepperdine Dispute Resolution Law Journal

$4-15-2013$

\section{"Final” Awards Reconceptualized: A Proposal to Resolve the Hall Street Circuit Split}

Matthew J. Brown

Follow this and additional works at: https://digitalcommons.pepperdine.edu/drlj

Part of the Dispute Resolution and Arbitration Commons

\section{Recommended Citation}

Matthew J. Brown, "Final" Awards Reconceptualized: A Proposal to Resolve the Hall Street Circuit Split, 13 Pepp. Disp. Resol. L.J. Iss. 2 (2013)

Available at: https://digitalcommons.pepperdine.edu/drlj/vol13/iss2/5

This Comment is brought to you for free and open access by the Caruso School of Law at Pepperdine Digital Commons. It has been accepted for inclusion in Pepperdine Dispute Resolution Law Journal by an authorized editor of Pepperdine Digital Commons. For more information, please contact bailey.berry@pepperdine.edu. 


\title{
"Final" Awards Reconceptualized: A Proposal to Resolve the Hall Street Circuit Split
}

\author{
Matthew J. Brown*
}

\section{INTRODUCTION}

Before the Supreme Court decided Hall Street Associates, L.L.C. v. Mattel, Inc., ${ }^{1}$ the federal appellate courts had generally agreed to the existence of non-statutory grounds for the vacatur of arbitral awards. ${ }^{2}$

Among these grounds, every circuit had adopted some form of the "manifest disregard of the law" (manifest disregard) standard. ${ }^{3} \quad$ Manifest disregard most commonly refers to the principle that a court may vacate an arbitration award if the arbitrator knows that a law applies and deliberately disregards

\footnotetext{
* Matthew J. Brown is a recent graduate of George Mason University School of Law, where he served as a Notes Editor for the George Mason Law Review. While in law school, he received a certificate in global arbitration law and practice from Hamline University School of Law, in cooperation with Queen Mary, University of London. Before law school he obtained a B.A. from Wake Forest University. He is currently Research Director at the Institute of International Banking Law and Practice. He is also coaching the Kabul University Vis Moot Team in the 11th Willem C. Vis (East) International Commercial Arbitration Moot. The author would like to thank Professors Ross E. Davies and Thomas E. Carbonneau for their thoughtful suggestions during the writing process, and Angela Diveley and Brian Ziff-Levine for their invaluable editing advice. Most importantly, he would like to thank his fiancée Kristin Gilroy for her love, patience, and support without which this Comment would not have been possible.

1. 552 U.S. 576 (2008).

2. Stephen L. Hayford, A New Paradigm for Commercial Arbitration: Rethinking the Relationship Between Reasoned Awards and the Judicial Standards for Vacatur, 66 GEO. WASH. L. REV. 443, 450-51 (1998).

3. Reid S. Manley \& Zachary D. Miller, Disregarding "Manifest Disregard": The Effect of Hall Street Associates, LLC v. Mattel, Inc. and Its Progeny on the Standard for Arbitral Review, FDCC Q., at 357, 360 (Summer 2010) (citing Montes v. Shearson Lehman Bros., 128 F.3d 1456, 1460 (11th Cir. 1997)); accord James E. Berger \& Charlene Sun, The Evolution of Judicial Review Under the Federal Arbitration Act, 5 N.Y.U. J.L. \& Bus. 745, 763 (2009) ("Following Wilko, every circuit ultimately adopted manifest disregard of the law as a separate ground for vacatur of an award."); Richard C. Reuben, Personal Autonomy and Vacatur after Hall Street, 113 PENN ST. L. REv. 1103, 1111 (2009); Ann C. Gronlund, Note, The Future of Manifest Disregard as a Valid Ground for Vacating Arbitration Awards in Light of the Supreme Court's Ruling in Hall Street Associates v. Mattel, Inc., 96 IowA L. REv. 1351, 1359 (2011).
}

325 
it, rather than vacating the award for misunderstanding or misapplication of the law. ${ }^{4}$ When the Supreme Court granted certiorari in Hall Street, it did so solely to answer the question whether the Federal Arbitration Act (FAA). ${ }^{5}$ "preclude[d] a federal court from enforcing the parties' clearly expressed agreement providing for more expansive judicial review of an arbitration award." However, in the process of answering this question, the Court inadvertently cast doubt on the continued validity of all non-statutory grounds for vacatur. ${ }^{7}$ In the wake of Hall Street, a sharp split has occurred among the circuit courts as to the continuing validity of manifest disregard. ${ }^{8}$

The FAA does not grant courts the authority to review the merits of an arbitrator's decision. ${ }^{9}$ Yet, despite the doctrine's widespread acceptance,

4. Black’s LaW Dictionary 1048 (9th ed. 2009); see McCarthy v. Citigroup Global Mkts. Inc., 463 F.3d 87, 91-92 (1st Cir. 2006) (“[W]e mean by 'manifest disregard of the law' a situation 'where it is clear from the record that the arbitrator recognized the applicable law - and then ignored it."”) (quoting Advest, Inc. v. McCarthy, 914 F.2d 6, 9 (1st Cir. 1990)); Hiro N. Aragaki, The Mess of Manifest Disregard, 119 YALE L.J. ONLINE 1, 1 (2009), http://www.yalelawjournal.org/images/ pdfs/817.pdf ("Manifest disregard is a common-law exception to the limited grounds for vacatur of arbitral awards enumerated in the Federal Arbitration Act (FAA). [The] doctrine empowers courts to refuse to enforce awards that evince a 'manifest disregard of the law,' understood to mean a willful defiance of clearly applicable law, not just garden-variety legal error.”).

5. 9 U.S.C. $\S \S 1-16(2006)$.

6. Petition for a Writ of Certiorari at i, Hall St. Assocs., L.L.C. v. Mattel, Inc., 552 U.S. 576 (2008) (No. 06-989); see Hall St. Assocs., 552 U.S. at 581.

7. Aragaki, supra note 4, at 3 ('If the FAA standards are 'exclusive,' are judicially-crafted vacatur standards-which almost all circuits have recognized in the guise of 'manifest disregard,' ... -no longer viable?" (footnote omitted)).

8. Compare Frazier v. CitiFinancial Corp., 604 F.3d 1313 (11th Cir. 2010), Med. Shoppe Int'l, Inc. v. Turner Invs., Inc., 614 F.3d 485 (8th Cir. 2010), and Citigroup Global Mkts., Inc. v. Bacon, 562 F.3d 349 (5th Cir. 2009), with Comedy Club, Inc. v. Improv West Assocs., 553 F.3d 1277 (9th Cir. 2009), \& Stolt-Nielsen SA v. Animal Feeds Int'l Corp., 548 F.3d 85 (2d Cir. 2008), rev'd on other grounds, 130 S. Ct. 1758 (2010).

9. See Amy J. Schmitz, Ending a Mud Bowl: Defining Arbitration's Finality Through Functional Analysis, 37 GA. L. REv. 123, 132-33 n.48 (2002) (explaining that the drafters of the FAA specifically rejected the "English model that allowed judicial review of arbitration award for legal questions, and . . . insiste[d] that 'once the parties have agreed upon arbitration, they must accept the result the arbitrator reaches no matter how obviously and plainly wrong it appears"') (quoting Wharton Poor, Arbitration Under the Federal Statute, 36 YALE L.J. 667, 676-78 (1927)). Courts and commentators take this notion for granted today. So much so, they often do not even provide citations when making the claim, perhaps believing the notion self-evident from the statute. See, e.g., First Options of Chi., Inc. v. Kaplan, 514 U.S. 938, 942 (1995) ("[A] party who has not agreed to arbitrate will normally have a right to a court's decision about the merits of its dispute (say, as here, its obligation under a contract). But, where the party has agreed to arbitrate, he or she, in effect, has relinquished much of that right's practical value."); Biller v. Toyota Motor Corp., No. 11-55587, 2012 WL 336135, at *6 (9th Cir. Feb. 3, 2012) ("Indeed, § 10 of the FAA provides no authorization for a merits review.”); White Springs Agric. Chems., Inc. v. Glawson Invs. Corp., 660 F.3d 1277, 1283 (11th Cir. 2011) ("Even though White Springs presents its argument in terms of the FAA, it asks us to do what we may not-look to the legal merits of the underlying award."); Southco, Inc. v. Reell Precision Mfg. Corp., 331 F. App’x 925, 927 (3d Cir. 2009) (explaining that 
[Vol. 13: 325, 2013]

PEPPERDINE DISPUTE RESOLUTION LAW JOURNAL

courts and commentators alike have questioned and condemned manifest disregard as a potential "back door" to merits review. ${ }^{10}$ In its Hall Street decision, the Court likewise displayed uneasiness with manifest disregard, focusing its attention on the underpinnings of the doctrine. ${ }^{11}$ This seems to suggest the tenuous footing manifest disregard currently holds will give way, and the Court will officially eliminate the doctrine. Nonetheless, the Court has remained reluctant to jettison the nearly fifty-year-old doctrine. ${ }^{12}$

Seeking to ease the reluctance, this Comment argues that manifest disregard's inconsistencies with arbitration's "benefits of the bargain" should lead to dismissal of manifest disregard. The prospect of the Court formally abandoning manifest disregard has set off alarm bells for some. One commentator even went so far as to state that "[i]f 'manifest disregard' is eliminated, arbitral finality will rise above the crowning principle of the American constitutional system: 'No man in this country is so high that he is above the law.",13 However, absent manifest disregard, the FAA had

"parties to the contract may not appeal the merits of the arbitration"); Brief of Arbitration Professors Richard C. Reuben, et al. as Amici Curiae in Support of Plaintiffs-Appellants and Reversal of the District Court Order, Jock v. Sterling Jewelers Inc., 646 F.3d 113 (2d Cir. 2011) (No. 10-3247-cv), available at http://law.missouri.edu/news/pdf/reuben_amicus_brief.pdf; THOMAS E. CARBONNEAU, CASEs AND Materials on the LAW AND PRACTICE oF ARBitration 541 (5th ed. 2009) (summarily stating that "FAA § 10 does not recognize merits review").

10. E.g., Baravati v. Josephthal, Lyon \& Ross, Inc., 28 F.3d 704, 706 (7th Cir. 1994) (Posner, J.) ("If [manifest disregard] is meant to smuggle review for clear error in by the back door, it is inconsistent with the entire modern law of arbitration."); CARBONNEAU, supra note 9, at 541 ("[T] he common-law grounds [including manifest disregard] appear to authorize the courts to review the merits of arbitral determinations."); Aragaki, supra note 4, at 1 ("[Manifest disregard] opens the door to judicial review of the legal merits of arbitral awards, which modern arbitration law has long viewed as inimical to core process values such as efficiency and finality.").

11. See Hall St. Assocs., 552 U.S. at 585 ("Then there is the vagueness of Wilko's phrasing. Maybe the term 'manifest disregard' was meant to name a new ground for review, but maybe it merely referred to the $\S 10$ grounds collectively, rather than adding to them."); infra Part I.C. (discussing the history and development of manifest disregard).

12. To date, the Court has granted certiorari for only one case in which manifest disregard was at issue; however, the Court specifically declined to decide the continued validity of manifest disregard. Stolt-Nielsen S.A. v. AnimalFeeds Int'l Corp., 130 S. Ct. 1758, 1767-68 n.3 (2010) ("We do not decide whether 'manifest disregard' survives our decision in [Hall Street] as an independent ground for review or as a judicial gloss on the enumerated grounds for vacatur set forth at 9 U.S.C. $\S 10 . ")$.

13. Michael H. LeRoy, Are Arbitrators Above the Law? The "Manifest Disregard of the Law" Standard, 52 B.C. L. REV. 137, 137 (2011).

327 
already granted courts the authority to review arbitral awards without disturbing their merits. ${ }^{14}$

While the arbitration process provides the mechanism for the resolution of disputes, it possesses no internal mechanism for enforcement. If a disappointed party refuses to abide by an arbitral award, the prevailing party must then turn to a court to seek enforcement. ${ }^{15}$ Accordingly, the arbitration process rests on the foundation that a court will enforce the arbitral award. ${ }^{16}$ At least in the international context, where a court finds an award unenforceable, that award demonstrates a lack of finality. ${ }^{17}$ This Comment suggests a common sense approach, since there is nothing truly final about an unenforceable arbitral award. Specifically, this Comment argues that the word "final," as it appears in FAA § 10(a)(4), ${ }^{18}$ requires the enforceability of an award in addition to its traditional definition. In practice, the reconceptualization consists of a two-step process. A court must first determine whether an award, as written, is enforceable and therefore "final" under section 10(a)(4). If, on the other hand, the award is not final, the court must then decide whether the award can be modified without disturbing its merits under section $11(\mathrm{c}){ }^{19}$

14. The FAA provides courts with three options for the review of arbitral awards: enforcement, vacatur or modification. 9 U.S.C. $\S \S 9-11$ (2006).

15. See Berger \& Sun, supra note 3, at 748 ("The private practice of arbitration [is] of little practical use without the authority of court enforcement ....."); see also Richard C. Reuben, Process Purity and Innovation: A Response to Professors Stempel, Cole, and Drahozal, 8 NEV. L.J. 271, 282 (2007) ("[E]nforceability is crucial because many parties can reasonably be expected simply to ignore an adverse award if it is not binding.").

16. See Reuben, supra note 15, at 282 ("Without enforceability, arbitrators would only be able to issue what in effect would be advisory opinions.").

17. Alan REDFERn \& Martin HUNTER, LAW AND PRACTICE OF InTERnAtional COMMERCIAL ARBitration 419 (2d ed. 1991). "Lack of finality of an award may manifest itself in a number of ways, and lead to refusal of enforcement under the provisions of law governing the recognition and enforcement of judgments." Id.

18. The subsection provides as follows:

(a) In any of the following cases the United States court in and for the district wherein the award was made may make an order vacating the award upon the application of any party to the arbitration-

(4) Where the arbitrators exceeded their powers, or so imperfectly executed them that a mutual, final, and definite award upon the subject matter submitted was not made.

9 U.S.C. § 10(a)(4).

19. Federal Arbitration Act $\S 11(\mathrm{c})$ allows "the United States court in and for the district wherein the award was made may make an order modifying or correcting the award upon the application of any party to the arbitration-... [w] were the award is imperfect in matter of form not affecting the merits of the controversy. The order may modify and correct the award, so as to effect the intent thereof and promote justice between the parties." 9 U.S.C. § 11(c). 
[Vol. 13: 325, 2013]

PEPPERDINE DISPUTE RESOLUTION LAW JOURNAL

Part I describes the histories of arbitration, the FAA, the finality of arbitral awards, and the manifest disregard doctrine, emphasizing the way in which the doctrine deprives parties of the benefits of the arbitration bargain. Part II describes the circuit split over the continued validity of manifest disregard as either a valid or invalid statutory or non-statutory ground for vacatur. Finally, Part III resolves the split by abolishing manifest disregard and then reconceptualizing "final" as currently understood under section 10(a)(4) through the two-step procedure. ${ }^{20}$

\section{A BRIEF BACKGROUND OF ARBITRATION AND ARBITRATION LAW IN THE UNITED STATES}

\section{A. Arbitration and the Benefits of the Arbitration Bargain}

Arbitration as a mechanism for dispute resolution has existed since some of the earliest days of recorded history. ${ }^{21}$ The arbitration process developed because parties wished to resolve their disputes in a more efficient and expeditious manner than that provided by traditional courts. ${ }^{22}$ The arbitration process formalized and expanded with the development of Lex Mercatoria (Law Merchant). ${ }^{23}$ The Law Merchant evolved in the early Court Merchant fairs where itinerant merchants valued efficiency and finality in the resolution of disputes, since, as traveling merchants, they

20. The scope of this Comment pertains to arbitrations as originally envisioned by the FAA, namely as a mechanism for dispute resolution between sophisticated commercial parties who bargained at arms' length. See Julius Henry Cohen \& Kenneth Dayton, The New Federal Arbitration Law, 12 VA. L. REV. 265, 279 (1926) ("Arbitration under the Federal and similar statutes is simply a new procedural remedy, particularly adapted to the settlement of commercial disputes.... No one is required to make an agreement to arbitrate. Such action by a party is entirely voluntary.") Compare id. at 278 ("An agreement for arbitration is a business contract."). To the extent that arbitration has expanded beyond this original context, many of the same principles can and should be applied; however, such application warrants further scholarship. For such a discussion included in the context of abandoning the manifest disregard standard, see generally, Michael A. Scodro, Deterrence and Implied Limits on Arbitral Power, 55 DukE L.J. 547 (2005).

21. Cohen \& Dayton, supra note 20, at 266; see Reuben, supra note 15, at 279 ("Arbitration became formalized in the commercial context with the rise of the craftsmen's gilds and Court Merchant fairs of the twelfth and thirteenth centuries.").

22. See Reuben, supra note 3, at 1104 (describing the "very predicate" of arbitration and the alternative dispute resolution process generally as the notion that "parties can do a better job of resolving their disputes through private ordering than public courts can through public ordering").

23. Reuben, supra note 15, at 279. 
could not remain long in a single community. ${ }^{24}$ The Law Merchant became "a special law administered by special Courts for a special class of people." ${ }^{25}$ In other words, the Law Merchant and its arbitration process developed alongside and outside of the common law. ${ }^{26}$

Under the Law Merchant, in contrast to the common law, arbitration did not develop a unified code of substantive principles, instead largely remaining a matter of free decision. ${ }^{27}$ In place of the substantive principles, fellow merchants would judge each case in terms of practical expediency, often grounding their decisions in the ethical or economic norms of the particular groups to which the disputing merchants belonged. ${ }^{28}$ After a dispute arose, but prior to the commencement of arbitration, the parties delegated the authority to resolve the dispute to the arbitrators through a contract or sometimes as a requirement of membership in a particular merchant gild. ${ }^{29}$

To proceed to arbitration in modern times, parties must formally agree to arbitrate their disputes. ${ }^{30}$ As a result, arbitration is a creature of contract. ${ }^{31}$ Within the arbitration agreement, parties may consent to a set of governing adjudication principles and procedures by which a neutral third party shall resolve the dispute. $^{32}$ Essentially, the arbitration agreement acts as an optout provision from the court system, bypassing traditional judges in favor of

24. Id. (footnote omitted).

25. Id. at 279 n.44 (quoting Thomas Edward Scrutton, General Survey of the History of the Law Merchant, in 3 Select EsSAYS IN ANGLO-AMERICAN LEgAl History 7, 9 (1909)).

26. Windham Anstis Bewes, The Romance of the LaW Merchant (Fred B. Rothman \& Co. 1986) (1923) (describing "the custom of merchants [as being] recognized as a law apart from the common law"); see also Berger \& Sun, supra note 3, at 747 ("Law Merchant [] developed in England to address the particular needs of merchants that the common law did not serve."). For an extended discussion on the history of conflict between the Law Merchant and the common law, see JULIUS HENRY COHEN, COMMERCIAL ARBITRATION AND THE LAW 71-83 (1918).

27. Earl S. Wolaver, The Historical Background of Commercial Arbitration, 83 U. PA. L. REV. 132, 132 (1934).

28. $I d$.

29. Id. at 133.

30. Carbonneau, supra note 9, at 2; see Cohen \& Dayton, supra note 20, at 281 (“Arbitration under the law depends upon a written instrument.").

31. See 9 U.S.C. § 2 (2006); First Options of Chi., Inc. v. Kaplan, 514 U.S. 938, 943 (1995) ("Arbitration is simply a matter of contract between the parties; it is a way to resolve those disputes - but only those disputes - that the parties have agreed to submit to arbitration."); H.R. REP. No. 68-96, at 1 (1924) ("Arbitration agreements are purely matters of contract ...."); see Cohen \& Dayton, supra note 20, at 278 ("An agreement for arbitration is a business contract. It should be as inviolable as any other business contract, and once it is violated the law should give an adequate remedy.").

32. See Reuben, supra note 3, at 1104; see Berger \& Sun, supra note 3, at 747 (describing the "grant of powers to arbitrators via submission to the process").

330 
[Vol. 13: 325, 2013]

PEPPERDINE DISPUTE RESOLUTION LAW JOURNAL

a neutral third party. ${ }^{33}$ When the parties consent, the agreement binds them to the arbitrator's determination. ${ }^{34}$

As with other bargained-for exchanges, arbitration has benefits to its bargain. ${ }^{35}$ Among them, finality and efficiency stand out as the primary benefits of the arbitration bargain. ${ }^{36}$ To avoid the inflexible adherence to substantive and procedural law promised by the court system, "parties often agree to arbitrate precisely because they desire a streamlined process that emphasizes efficiency and the preservation of business relationships over technical fidelity to the law." ${ }^{, 37}$ Indeed, as Professor Richard Reuben observes, "the notion of substantive 'correctness' or 'accuracy' historically has had little place in arbitration precisely because arbitration calls for the exercise of worldly judgment that is informed by a variety of considerations that may not lend themselves to an objective notion of correctness or accuracy." 38 By bargaining for a streamlined and final process, parties to arbitration opt out of the high costs, long delays, and contentious discovery that often attend litigation. ${ }^{39}$ In other words, the benefit of the arbitration

33. Wise v. Wachovia Sec., LLC, 450 F.3d 265, 269 (7th Cir. 2006); Reuben, supra note 3, at 1104 ("[A]rbitration empowers parties to choose to opt out of public ordering from the outset ....").

34. See Reuben, supra note 15, at 282 ("Like those of public judges, the decisions of commercial arbitrators are fully enforceable by the public courts when the parties agree that the award is to be binding ...."); see also Cohen \& Dayton, supra note 20, at 267 ("A written provision for arbitration ... is made valid, enforceable and irrevocable, except upon the grounds for which any contract may be revoked.") (internal quotations omitted).

35. See 1 Samuel Williston \& Richard A. Lord, A Treatise on the LaW of Contracts $\S 1: 1$ (4th ed.1993 \& Supp. 2011) [hereinafter WILLISTON ON CONTRACTS] ("The goal of contract law is to hold parties to their agreements so that they receive the benefits of their bargains."); cf. 2 ARTHUR Linton Corbin, CoRBin on Contracts § 5.1 (Joseph M. Perillo ed., rev. ed. 1999 \& Supp. 2011) (identifying bases for the enforcement of an informal contract at common law as including "something given as an agreed exchange, benefits received by the promisor, [or] detriments incurred by the promisee"); id. at $\S 5.9$ ("There is no doubt that most enforceable promises are made by the promisor for the purpose of getting in return something that the promisor regards as beneficial. Promises are made to pay for work, goods or title to land. If bargained for, these beneficial subjects of exchange are consideration for a promise.").

36. See Aragaki, supra note 4, at 1 (referring to finality and efficiency as the "core process values" of arbitration); Hayford, supra note 2, at 505 (describing the final and binding nature of the arbitrator's award as the "bargain inherent in the agreement to arbitrate"); Stephen L. Hayford, Reining in the "Manifest Disregard" of the Law Standard: The Key to Restoring Order to the Law of Vacatur, 1998 J. DisP. RESOL. 117, 118 (1998) (describing finality as "the process['s] . . . most essential feature").

37. Aragaki, supra note 4, at 11.

38. Reuben, supra note 15, at 282.

39. Gilmer v. Interstate/Johnson Lane Corp., 500 U.S. 20, 31 (1991) ("[A] party "trades the procedures and opportunity for review of the courtroom for the simplicity, informality, and 331 
bargain consists of the finality and efficiency of the arbitrator's decision because that is what the parties have bargained for in place of a traditional court proceeding. ${ }^{40}$

Similar to other types of contracts, arbitration agreements involve risks particular to their bargain. ${ }^{41}$ This risk lies in the potentially adverse arbitral decision coupled with limited judicial review. ${ }^{42}$ As stated though, this risk is balanced by a potentially favorable arbitral award coupled with the adversary's limited right to judicial review. ${ }^{43}$ Arbitration also includes the inherent risk of what Professor Reuben terms "abnormal awards." 44 This potential cannot be allowed to undermine the arbitral process, however, because "the possibility of the abnormal award is simply one of those risks that is a part of the parties' bargain to arbitrate." 45 As such, parties must account for this risk at the contracting stage, rather than at the enforcement stage when one of the parties has already realized part of the bargain. After all, freely entered arbitration agreements have the same force of law as any other contract. ${ }^{46}$ As Professor Samuel Williston once noted:

The goal of contract law is to hold parties to their agreements so that they receive the benefits of their bargains. It is not the function of the courts to relieve a party to a freely

expedition of arbitration."') (quoting Mitsubishi Motors Corp. v. Soler Chrysler-Plymouth, Inc., 473 U.S. 614, 628 (1985); Reuben, supra note 3, at 1129-30; Reuben, supra note 15, at 279 ("[A]rbitration can be faster and cheaper than the courts, in part because it averts the long waiting time for a trial in some jurisdictions, the large legal and expert witness fees generated by extensive pre-trial discovery and long, complex trials, and the delay to the implementation of an adjudicatory decision that can be caused by appeals.").

40. Brad A. Galbraith, Note, Vacatur of Commercial Arbitration Awards in Federal Court: Contemplating the Use and Utility of the "Manifest Disregard" of the Law Standard, 27 IND. L. REV. 241, 259-60 (1993) (quoting Davis v. Chevy Chase Fin. Ltd., 667 F.2d 160, 165 (D.C. Cir. 1981)).

41. See Williston ON ConTracts, supra note 35, at $\S 1: 1$ ("[Contract law] is intended to enforce the expectancy interests created by the parties' promises so that they can allocate risks and costs during their bargaining."); cf. N. Ind. Pub. Serv. Co. v. Carbon Cnty. Coal Co., 799 F.2d 265 (7th Cir. 1986) (Posner, J.) (describing the "normal risk of a fixed-price contract" as the possibility "that the market price will change. If it rises, the buyer gains at the expense of the seller . . . if it falls, as here, the seller gains at the expense of the buyer.").

42. See Baravati v. Josephthal, Lyon \& Ross, Inc., 28 F.3d 704, 706 (7th Cir. 1994) ("By including an arbitration clause in their contract the parties agree to submit disputes arising out of the contract to a nonjudicial forum, and we do not allow the disappointed party to bring his dispute into court by the back door, arguing that he is entitled to appellate review of the arbitrators' decision.'); cf. Reuben, supra note 3, at 1148.

43. See supra note 39.

44. Reuben, supra note 3, at 1148. Although arbitration lacks the appellate procedures of traditional adjudication that serve to "correct" or "normalize" judgments that might fall outside of party expectations, this should not surprise parties to an arbitration proceeding, because "[w]hen they contract to take their cases out of the public system, parties are opting for an informal system of 'rough justice."' Id.

45. See id.

46. Galbraith, supra note 40, at 259. 
As a creature of contract, the tenets of contract law hold particular significance to arbitration jurisprudence.

\section{B. The Federal Arbitration Act}

At the same time arbitration developed as a means to resolve commercial disputes, judicial animosity emerged against the enforcement of arbitration agreements. ${ }^{48}$ English common law courts jealously guarded their jurisdiction due to a concern that the specific enforcement of arbitration agreements might impede or interfere with the regular judicial administration of justice. ${ }^{49}$ This hostility developed before the common law doctrine of binding contracts had fully formed. ${ }^{50}$ However, as contracts became recognized as binding, arbitration agreements lagged behind and judicial hostility persisted. ${ }^{51}$ Then, with the adoption of English common law, the judicial hostility toward arbitration agreements became incorporated in America. ${ }^{52}$ Unlike England, however, the special institutions that supported the Law Merchant did not follow mercantilism to America, leaving colonial merchants to find new ways of resolving their trade disputes. $^{53}$

Flourishing commerce in the United States highlighted the need for decreased judicial hostility toward the enforcement of arbitration agreements, finally coming to a head in the late 1910s. ${ }^{54}$ Although hesitant to enforce agreements, judges were more willing to enforce awards rendered

47. WiLLISTON ON CONTRACTS, supra note 35, at § 1:1.

48. Berger \& Sun, supra note 3, at 746-47.

49. Id. (quoting Home Ins. Co. v. Morse, 87 U.S. 445, 452 (1874)) (alterations original). For an extended discussion of the common law doctrines of ouster and revocability by which courts refused to enforce arbitration agreements, see Wolaver, supra note 27, at 138-44. See also Berger \& Sun, supra note 3, at 747-48.

50. COHEN, supra note 26, at 60-70; Berger \& Sun, supra note 3, at 748 n.15.

51. Berger \& Sun, supra note 3, at 748 n.15 (citing Bruce L. Benson, An Exploration of the Impact of Modern Arbitration on the Development of Arbitration in the United States, 11 J.L. ECON. \& ORG. 479, 489 (1995)).

52. Galbraith, supra note 40, at 245; see Mitsubishi Motors Corp. v. Soler Chrysler-Plymouth, Inc., 473 U.S. 614, 625 n.14 (1985) (describing "an anachronistic judicial hostility to agreements to arbitrate, which American courts had borrowed from English common law.”).

53. Berger \& Sun, supra note 3, at 747.

54. Id. at $748-53$. 
after the parties had submitted their disputes to arbitration. ${ }^{55}$ In fact, some courts did not philosophically oppose enforcing arbitration agreements but for the persistence of the old common law doctrines which handcuffed these judges from enforcing the agreements. ${ }^{56}$ Hence, the need arose to remove the old common law doctrines and to give judges the proper tools to enforce arbitration agreements. ${ }^{57}$ This climate of unenforceable agreements yet enforceable awards provided the backdrop for the drafting of the FAA. As a result, the statute focuses on the enforcement of arbitration agreements rather than awards. ${ }^{58}$

The New York Chamber of Commerce, a driving force behind the drafting of the FAA, wished to have a federal law to complement the newly enacted New York state law, which enforced arbitration agreements. ${ }^{59}$ At the time, federal courts sitting in diversity jurisdiction refused to enforce arbitration agreements without a federal statute. ${ }^{60}$ Enacted in 1925 as the United States Arbitration Act, the FAA consists of sixteen provisions, "most of which are quite brief" and "relatively cryptic." 61 The heart of the act, contained in section 2, provides for the enforcement of valid arbitration

55. Thomas E. Carbonneau, The Revolution in Law Through Arbitration, 56 CLEV. ST. L. REV. 233, 244 (2008); Cohen \& Dayton, supra note 20, at 270; e.g., Burchell v. Marsh, 58 U.S. 344, 345 (1854) ("If the award is within the submission, and contains the honest decision of the arbitrators, after a full and fair hearing of the parties, a court of equity will not set it aside for error, either in law or fact. A contrary course would be a substitution of the judgment of the chancellor in place of the judges chosen by the parties, and would make an award the commencement, not the end, of litigation.").

56. Arbitration of Interstate Commercial Disputes: Joint Hearings on S. 1005 and H.R. 646 Before the Subcomms. of the Comms. on the Judiciary, 68th Cong. 38-39 (1924) [hereinafter Joint Hearings] (brief of Julius Henry Cohen) (citing U.S. Asphalt Ref. Co. v. Trin. Lake Petrol. Co., 222 F. 1006 (S.D.N.Y. 1915); President of Del. \& Hudson Canal Co. v. Pa. Coal Co., 50 N.Y. 250 (1872)); Cohen \& Dayton, supra note 20, at 274-75, 283 (citing same).

57. See Berger \& Sun, supra note 3, at 752 (describing the New York Arbitration Law - the precursor and model for the FAA-as "provid[ing] the tools to the courts for enforcing a valid agreement to arbitration").

58. Michael H. LeRoy \& Peter Feuille, Happily Never After: When Final and Binding Arbitration Has No Fairy Tale Ending, 13 HARV. NEGOT. L. REV. 167, 170 (2008); Gronlund, supra note 3, at 1356-57; see Dean Witter Reynolds, Inc. v. Byrd, 470 U.S. 213, 219 (1985) ("[T]he purpose behind [the FAA's] passage was to ensure judicial enforcement of privately made agreements to arbitrate."); Reuben, supra note 15, at 285 ("The primary purpose of the FAA was narrow: to repeal the centuries-old 'ouster' or 'revocability' doctrine, under which both English and American courts refused to enforce commercial agreements to arbitrate.") (internal citations omitted).

59. Carbonneau, supra note 55, at 245 (citation omitted).

60. Id. (citation omitted).

61. United States Arbitration Act, Pub. L. No. 68-401, ch. 213, 43 Stat. 883 (1925) (codified as amended at 9 U.S.C. §§ 1-16 (2006)); Carbonneau, supra note 55, at 246 n.54. 
[Vol. 13: 325, 2013]

PEPPERDINE DISPUTE RESOLUTION LAW JOURNAL

agreements in the same manner as any other enforceable contract. ${ }^{62}$ The FAA then lays out the procedure for the enforcement of arbitral awards except in certain circumstances such as fraud or corruption. ${ }^{63}$ In the event of ambiguity or mistake, the FAA also provides for limited judicial modification of arbitral awards so long as the merits of the controversy remain unaffected. ${ }^{64}$ As Professor Thomas Carbonneau points out, "[t]he FAA's central provisions are sections $1,2,3$, and $10-2$ and 10 are all that is really necessary." 65 Whatever grounds for vacatur that do exist, the language of section 10 completely excludes the review of the merits of arbitral decisions. ${ }^{66}$ For the purposes of this Comment, section 10(a)(4) lists the relevant and disputed grounds for vacatur of an award. ${ }^{67}$

\section{Functus Officio and the Finality of Arbitral Awards}

As the Second Circuit stated in 1980, "[i]n order to be 'final,' an arbitration award must be intended by the arbitrators to be their complete determination of all claims submitted to them." ${ }^{, 68} \quad$ This statement encompasses the traditional notion of arbitral finality, where an arbitral award is only considered "final" under § 10(a)(4) if it resolves the dispute to such an extent that the parties need not litigate further to finalize their obligations. ${ }^{69}$ However, this does not exhaust the discussion of arbitral finality. While the judiciary still remained hostile to arbitration, judges developed a doctrine aimed at "protecting" arbitrators who-lacking the same institutional protections as judges - might be susceptible to outside

62. 9 U.S.C. § 2. By allowing the federal judiciary to enforce valid arbitration agreements, this section enacted the overriding principle for the FAA's drafting. See supra note 57 and accompanying text.

63. 9 U.S.C. $\S \S 9-10$.

64. 9 U.S.C. § 11.

65. Carbonneau, supra note 55, at 246.

66. 9 U.S.C. § 10; Carbonneau, supra note 55, at 248; see Hayford, supra note 2, at 450 ("Nothing in section 10(a) . . . authorizes the courts to engage in substantive review of the merits ... of ... arbitration awards."); Hayford, supra note 36, at 117 ("On its face, Section 10(a) does not sanction judicial inquiry of any sort into the merits of ... arbitration awards.").

67. See 9 U.S.C. § 10(a)(4) (describing two separate grounds for vacatur "where the arbitrators exceeded their powers, or so imperfectly executed them that a mutual, final, and definite award upon the subject matter was not made").

68. Michaels v. Mariforum Shipping, S.A., 624 F.2d 411, 413 (2d Cir. 1980).

69. Reuben, supra note 3, at 1110 (citing Conn. Tech. Dev. Co. v. Univ. of Conn. Educ. Props., 102 F.3d 677, 686 (2d Cir. 1996)); see also CARBONNEAU, supra note 9, at 80 (explaining that under $\S 10$ an arbitrator "must provide the parties with a ruling that resolves the dispute").

335 
pressures to revisit awards. $^{70}$ Latin for "task performed" or "office performed," the doctrine came to be known as functus officio. ${ }^{71}$

The Supreme Court defined the common-law rule in its 1863 decision Bayne v. Morris ${ }^{72}$ as follows: "Arbitrators exhaust their power when they make a final determination on the matters submitted to them. They have no power after having made an award to alter it; the authority conferred on them is then at an end." ${ }^{, 73}$ Judge Richard Posner explained the doctrine further:

\begin{abstract}
The doctrine is based on the analogy of a judge who resigns his office and, having done so, naturally cannot rule on a request to reconsider or amend his decision. Arbitrators are ad hoc judges - judges for a case; and when the case is over they cease to be judges and go back to being law professors or businessmen or whatever else they are in private life, like Cincinnatus returning to his plow. The flaw in the analogy is that the judge's resignation does not deprive litigants of an opportunity to seek reconsideration of his decisions. Motions to reconsider are simply directed to another judge. If the "resignation" of the arbitrator from the case, in accordance with the doctrine of functus officio, disables him from considering a motion for reconsideration, clarification, amendment, or other modification, there is nobody to whom the parties can turn. The result would be a gap in the system of arbitral justice that would make very little sense that we can see. Not no sense. Once they return to private life, arbitrators are less sheltered than sitting judges, and it is feared that disappointed parties will bombard them with ex parte communications and that the arbitrators. not being professional judges or subject to the constraints of judicial ethics, will yield. ... ${ }^{74}$
\end{abstract}

Simply put, the doctrine bars arbitrators from reexamining the merits of a dispute once they have issued an award. ${ }^{75}$

At first glance, such a bar to reexamination seems to promote the finality of arbitration. ${ }^{76}$ However, denying arbitrators the ability to revisit awards allows uncertainties to foster, thereby actually producing greater fodder for litigation, reducing arbitral finality, and reducing arbitration's

70. Official \& Prof'l Emps. Int'l Union, Local No. 471 v. Brownsville Gen. Hosp., 186 F.3d 326, 331 (3d Cir. 1999). See Glass, Molders, Pottery, Plastics \& Allied Workers Int'l Union, Local 182B v. Excelsior Foundry Co., 56 F.3d 844, 845 (7th Cir. 1995) (Posner, J.) ("The doctrine originated in the bad old days when judges were hostile to arbitration and ingenious at hamstringing it. It is said to have been "nourished by the primitive view of the solemnity of all judgments."') (quoting La Vale Plaza, Inc. v. R.S. Noonan, Inc., 378 F.2d 569, 572 (3d Cir. 1967) (internal citations omitted).

71. Brownsville, 186 F.3d at 331; Excelsior Foundry, 56 F.3d at 845.

72. 68 U.S. (1 Wall.) 97 (1863).

73. Bayne, 68 U.S. (1 Wall.) at 99.

74. Excelsior Foundry, 56 F.3d at 846-47.

75. Brownsville, 186 F.3d at 331 (citing Teamsters Local 312 v. Matlack, Inc., 118 F.3d 985, 991 (3d Cir. 1997)); Excelsior Foundry, 56 F.3d at 845 ("The arbitrator has performed his office and having done so has been discharged from it.").

76. See La Vale Plaza, Inc. v. R.S. Noonan, Inc., 378 F.2d 569, 572 (3d Cir. 1967) (referring to functus officio as a "policy of finality").

336 
utility. ${ }^{77}$ Thus, as judicial hostility to arbitration tempered and the common law continued to develop, exceptions were carved out of the general doctrine of functus officio. ${ }^{78}$ The Third Circuit recognized three particular exceptions to the doctrine, including allowing arbitrators to correct an apparent error, to render an award on a missed issue, and to clarify an ambiguity. ${ }^{79}$

These exceptions do not jeopardize the award's finality because they do "not in any way violate any policy relating to arbitration and would be within the arbitrators' power to pursue on their own motion." ${ }^{80}$ Awards containing ambiguities only provide greater uncertainty and therefore fodder for litigation, increasing the likelihood for de novo judicial review. ${ }^{81}$ In essence, the exceptions do not harm finality because the judge seeks guidance for enforcement of the award rather than examining the merits of the decision itself. On the other hand, by its very nature, the opportunity for arbitrators to correct their awards creates a separate by-product antithetical to the arbitration bargain: delay.

\section{The Development of Manifest Disregard as a Non-statutory Ground for Vacatur}

Manifest disregard of law traces its roots to the Supreme Court's 1953 decision in Wilko v. Swan. ${ }^{82}$ The decision involved the invalidation of an arbitration agreement under the Securities Acts of $1933 .{ }^{83}$ Although not pertaining directly to the Court's decision, some lower courts grabbed onto specific language stated in dictum:

While it may be true ... that a failure of the arbitrators to decide in accordance with the provisions of the Securities Act would "constitute grounds for vacating the award pursuant to section 10 of the Federal Arbitration Act," (citation omitted) that failure

77. Excelsior Foundry, 56 F.3d at 847.

78. Id. at 846 ("Today, riddled with exceptions, it is hanging on by its fingernails ....").

79. Brownsville, 186 F.3d at 331 (quoting Colonial Penn Ins. Co. v. Omaha Indem. Co., 943 F.2d 327, 332 (3d Cir. 1991)).

80. La Vale, 378 F.2d at 573.

81. See Northrop Corp. v. Triad Int'l Mktg. S.A., 811 F.2d 1265, 1269 ("To now subject these decisions to de novo review would destroy the finality for which the parties contracted and render the exhaustive arbitration process merely a prelude to the judicial litigation which the parties sought to avoid.").

82. 346 U.S. 427 (1953), overruled on other grounds by, Rodriguez de Quijas v. Shearson/Am. Express, Inc., 490 U.S. 477 (1989).

83. Wilko, 346 U.S. at 438. For an expansive discussion of the Wilko decision see Galbraith, supra note 40 , at $248-50$.

337 
would need to be made clearly to appear. In unrestricted [agreements to arbitrate] . . . the interpretations of the law by the arbitrators, in contrast to manifest disregard[,] are not subject, in the federal courts, to judicial review for error in interpretation. ${ }^{8}$

The Court subsequently overruled Wilko in Rodriguez de Quijas v. Shearson/American Express, Inc. ${ }^{85}$ Despite the Court's rejection of the "old judicial hostility to arbitration," which it found pervaded the Wilko opinion ${ }^{86}$ the Court's Wilko dicta has managed to endure. ${ }^{87}$

Evolving almost exclusively in the lower courts, manifest disregard has not received much attention from the Supreme Court. ${ }^{88}$ In fact, prior to the Supreme Court's decision in Hall Street, the Court had only mentioned manifest disregard three times. ${ }^{89}$ Among those mentions, the Court's most "glowing" endorsement came in the form of parenthetical dicta. ${ }^{90}$ Despite the Wilko statement's lack of precedential value, it nonetheless helped to prompt the widespread adoption of manifest disregard by the lower courts. ${ }^{91}$

The most common approach to the doctrine came from the Second Circuit's decision in Merrill Lynch, Pierce, Fenner \& Smith v. Bobker. ${ }^{92}$

The Bobker approach essentially entails three parts: (1) the clear existence of a governing law, (2) where the arbitrator knew of the controlling law, and (3) yet the arbitrator "consciously disregarded or ignored the applicable law." ${ }^{.93}$ Despite the generality of this approach, the numerous circuit court

84. Wilko, 346 U.S. at 436-37 (quoting Wilko v. Swan, 201 F.2d 439, 445 (2d Cir. 1953)); see MyLinda K. Sims \& Richard A. Bales, Much Ado about Nothing: The Future of Manifest Disregard after Hall Street, 62 S.C. L. REV. 407, 414 (2010) ("Some lower courts latched on to the Wilko language and adopted the doctrine of manifest disregard ....”).

85. Rodriguez de Quijas v. Shearson/American Express, Inc., 490 U.S. 477 (1989).

86. Id. at 480 .

87. See Hayford, supra note 36, at 122 ("The broad acceptance of the 'manifest disregard' of the law ground by the U.S. Circuit Courts of Appeals demonstrates they do not question its legitimacy and continued viability.").

88. Sims \& Bales, supra note 84 , at 414. For an extensive discussion of the development of lower court approaches to manifest disregard, see Hayford, supra note 36, at 122-24; Galbraith, supra note 40 , at $250-54$.

89. Hayford, supra note 36, at 121-22 n.23.

90. First Options of Chi., Inc. v. Kaplan, 514 U.S. 938, 942 (1995) (citing Wilco v. Swan, 346 U.S. 427, 436-37 (1953)) (“[P]arties [are] bound by arbitrator's decision not in 'manifest disregard' of the law."); see Hayford, supra note 36, at 121-22 n.23 (dismissively describing this Kaplan mention as simply "a parenthetical phrase in dictum").

91. Sims \& Bales, supra note 84 , at 414 .

92. Merrill Lynch, Pierce, Fenner \& Smith v. Bobker, 808 F.2d 930 (2d Cir. 1986).

93. Sims \& Bales, supra note 84, at 413 (citing Stolt-Nielsen SA v. AnimalFeeds Int'l Corp., 548 F.3d 85, 93 (2d Cir. 2008), rev'd on other grounds, 130 S. Ct. 1758 (2010)); see Merrill Lynch, 808 F.2d at 933 ("The error must have been obvious and capable of being readily and instantly perceived by the average person qualified to serve as arbitrator. Moreover, the term 'disregard' implies that the arbitrator appreciates the existence of a clearly governing legal principle but decides to ignore or pay no attention to it.").

338 
[Vol. 13: 325, 2013]

PEPPERDINE DISPUTE RESOLUTION LAW JOURNAL

opinions applying a manifest disregard standard have failed to advance a unitary, clearly articulated, and easily replicated mode of analysis. ${ }^{94}$

A critical reason for this failure turns on whether an arbitrator has merely misinterpreted the law or manifestly disregarded it. ${ }^{95}$ As the Court stated in Wilko, "the arbitrator's conception of the legal meaning of ... statutory requirements . . . cannot be examined," because, "interpretations of the law by the arbitrators. . . are not subject. . . to judicial review for error in interpretation." ${ }^{96}$ As Judge James Oakes pondered, "How courts are to distinguish in the Supreme Court's phrase between 'erroneous interpretation' of a statute, or for that matter, a clause in a contract, and 'manifest disregard' of it, we do not know: one man's 'interpretation' may be another's 'disregard.' Is an 'irrational' misinterpretation a 'manifest disregard'?"' Without bright guidelines, courts and parties are left to determine the outer boundaries of the manifest disregard standard on their own. Moreover, because arbitrators often have no obligation to make formal findings of fact or to offer a rationale, courts can speculate about whether arbitrators have manifestly disregarded an applicable law or simply misinterpreted it. ${ }^{98}$ This, in effect, leaves the court to "divine [the] arbitral state of mind."

Under such an amorphous standard, judicial review of the merits of arbitral decisions becomes a clear possibility in spite of its total exclusion from FAA $\S 10$. Where manifest disregard allows courts to perform a de novo review without recognizing it as such, the doctrine is inconsistent with modern arbitration law. ${ }^{100}$ The primary reason for this inconsistency lies in

94. Hayford, supra note 36, at 122.

95. Courts do not disagree that manifest disregard should remain a narrow standard. Rather, the doctrine's ambiguity and variance pertains to where, exactly, the line exists between misinterpretation of law and manifest disregard of it. See, e.g., Al-Harbi v. Citibank, N.A., 85 F.3d 680, 682 (D.C. Cir. 1996) ("[Manifest disregard] cannot empower a District Court to conduct the same de novo review of questions of law than an appellate court exercises over lower court decisions. Indeed, we have in the past held that 'it is clear that [manifest disregard] means more than error or misunderstanding with respect to the law.'” (quoting Kanuth v. Prescott, Ball \& Turben, 949 F.2d 1175, 1178 (D.C. Cir. 1991)).

96. Wilko v. Swan, 346 U.S. 427, 436-37 (1953).

97. I/S Stavborg v. Nat'l Metal Converters, Inc., 500 F.2d 424, 430 n.13 (2d Cir. 1974).

98. Galbraith, supra note 40, at 260.

99. Hayford, supra note 36, at 135.

100. Baravati v. Josephtal, Lyon \& Ross, Inc., 28 F.3d 704, 706 (7th Cir. 1994). 
manifest disregard's plain incompatibility with the finality of arbitration. ${ }^{101}$ Simply put, manifest disregard frustrates the arbitration agreement and the benefit of its bargain. ${ }^{102}$

\section{HALL STREET AsSOCIATES AND THE CIRCUIT SPLIT}

On March 25, 2008, the Supreme Court sought to resolve a split among the circuit courts over the viability of expanded judicial review of arbitral awards by contract. ${ }^{103}$ By contracting for judicial review, parties to an arbitration agreement ask for the vacatur of arbitral awards that do not conform to legal standards agreed to in the arbitration agreement. ${ }^{104}$

However, in resolving the split, the Court in Hall Street raised new questions regarding judicial review of arbitral awards. ${ }^{105}$ These questions have led to a new circuit split over whether manifest disregard remains a valid ground for vacatur of arbitral awards. ${ }^{106}$

A. The Decision in Hall Street Associates, L.L.C. v. Mattel, Inc. and the New Circuit Split

In Hall Street, the Supreme Court held that parties could not contract for expanded judicial review because FAA $\S \S 10$ and 11 are the exclusive grounds for vacatur or modification of arbitral awards. ${ }^{107}$ The parties at issue in Hall Street agreed to arbitrate a dispute over an indemnification claim, which had remained unresolved after a bench trial of a landlordtenant dispute. ${ }^{108}$ The parties included a clause in their arbitration agreement which stated that the district court "shall vacate, modify or correct any award: (i) where the arbitrator's findings of facts are not supported by substantial evidence or (ii) where the arbitrator's conclusions of law are

101. Hayford, supra note 36, at 118 (“'[Manifest disregard] rob[s] the [arbitration] process of its most essential feature - finality - by giving parties disappointed with the result reached in arbitration reason to believe they may be able to circumvent objectionable awards by resort to the courts.").

102. See Galbraith, supra note 40, at 259 ("[P]roviding grounds for vacation outside the Federal Arbitration Act ... frustrates the intent of the parties who bargained for the arbitration process to resolve their disputes.").

103. Berger \& Sun, supra note 3, at 745.

104. Reuben, supra note 3, at 1117.

105. Maureen A. Weston, The Other Avenues of Hall Street and Prospects for Judicial Review of Arbitral Awards, 14 LEWIS \& CLARK L. REV. 929, 938 (2010); Gronlund, supra note 3, at 1363. at 1363.

106. Aragaki, supra note 4, at 1 ; Sims \& Bales, supra note 84 , at 424 ; Gronlund, supra note 3 ,

107. Hall St. Assocs., L.L.C. v. Mattel, Inc., 552 U.S. 576, 585-86 (2008).

108. Id. at 579. 
erroneous." ${ }^{\text {When }}$ the arbitral award-decided in favor of defendant Mattel — stated that Mattel owed no indemnification because the Oregon Drinking Water Quality Act did not apply to the terms of the lease, plaintiff Hall Street Associates filed a motion for vacatur on the ground that this exclusion constituted legal error. ${ }^{110}$ The district court agreed and vacated the award, remanding it to the arbitrator. ${ }^{111}$ On remand, the arbitrator applied the Oregon Act and reversed his decision. ${ }^{112} \quad$ Following an extremely complicated subsequent procedural history, the Supreme Court ultimately granted review. ${ }^{113}$

Although the question before the Court specifically pertained to the viability of contractually expanded judicial review, ${ }^{114}$ the Court also responded to Hall Street's argument that the Court's Wilko decision expanded the possibilities for judicial review beyond sections 10 and $11 .^{115}$

Hall Street argued that the Wilko dicta-from which the doctrine of manifest disregard derived ${ }^{116}$ — showed that sections 10 and 11 could not be the exclusive grounds for vacatur because manifest disregard was a further nonstatutory ground. ${ }^{117}$

In response, the Court rejected Hall Street's argument because the vagueness of the Wilko language did not support such a construction. ${ }^{118}$ The Court rooted its rejection on the grounds that Hall Street asked the Court to do exactly what the Wilko Court had refused - to find that arbitral awards may be reviewed for general legal error. ${ }^{119}$ Next, the Court displayed its uneasiness with manifest disregard by stating that "[m]aybe the term 'manifest disregard' was meant to name a new ground for review, but maybe it merely referred to the section 10 grounds collectively, rather than adding

109. Id.

110. Id. at 580 .

111. Id.

112. Id.

113. Id. For an in depth discussion of the facts and the complicated procedural history of Hall Street, see Berger \& Sun, supra note 3, at 770-71.

114. Hall St. Assocs., 552 U.S. at 581. For the specific question upon which the Court granted certiorari, see supra note 6 and accompanying text.

115. Hall St. Assocs., 552 U.S. at 581.

116. See supra Part I.C.

117. Hall St. Assocs., 552 U.S. at 584.

118. See id. at 585 ("Hall Street sees this supposed addition [of manifest disregard] to $\S 10$ as the camel's nose: if judges can add grounds to vacate (or modify), so can contracting parties. But this is too much for Wilko to bear.").

119. Reuben, supra note 3, at 1119-20. 
to them."120 The Court never definitively resolved this issue, instead confining its discussion of manifest disregard to dicta by simply concluding that "when speaking as a Court, [we] have merely taken the Wilko language as we found it, without embellishment, and now that its meaning is implicated, we see no reason to accord it the significance that Hall Street urges." 121 Accordingly, this language seemed to cast doubt on the continued validity of manifest disregard as a non-statutory ground without emphatically denouncing the doctrine. ${ }^{122}$ Since Hall Street, the circuit courts have grappled with the question, disagreeing over whether or not manifest disregard remains a valid ground for vacatur. ${ }^{123}$

\section{B. Manifest Disregard Does Not Survive as a Valid Ground for Vacatur in the Fifth, Eighth, and Eleventh Circuits}

Several courts have concluded that Hall Street sounded the death knell for manifest disregard. ${ }^{124}$ Most significantly, the Fifth, Eighth, and Eleventh Circuits have conclusively held that manifest disregard did not survive Hall Street as a valid ground for vacatur under the FAA. ${ }^{125}$ Additionally, the First Circuit indicated in a footnote that if the question presented itself, the Court would likely agree and formally abolish manifest disregard. ${ }^{126}$

In Citigroup Global Markets, Inc. v. Bacon, the Fifth Circuit concluded that "Hall Street restricts the grounds for vacatur to those set forth in section 10 of the ... [FAA], and consequently, manifest disregard of the law is no longer an independent ground for vacating arbitration awards under the FAA." 127 The Fifth Circuit reversed a district court's vacatur of an award when the panel of arbitrators intentionally did not follow a state law in

120. Hall St. Assocs., 552 U.S. at 585.

121. Id. (citing First Options of Chi., Inc. v. Kaplan, 514 U.S. 938, 942 (1995)).

122. See Berger \& Sun, supra note 3, at 770 ("After roughly fifty years of continuous use by the federal courts, manifest disregard was called into question by the United States Supreme Court in Hall Street Associates, L.L.C. v. Mattel, Inc.”). at 1363.

123. Aragaki, supra note 4, at 1; Sims \& Bales, supra note 84, at 424; Gronlund, supra note 3,

124. See Aragaki, supra note 4, at 3 ("There are currently two broad schools of thought on the issue. The first is that Hall Street spells the end of manifest disregard and, by implication, any other non-statutory vacatur ground.") (footnote omitted).

125. Weston, supra note 105, at 940.

126. Ramos-Santiago v. UPS, 524 F.3d 120, 124 n.3 (1st Cir. 2008) ("We acknowledge the Supreme Court's recent holding in Hall Street that manifest disregard of the law is not a valid ground for vacating or modifying an arbitral award in cases brought under the Federal Arbitration Act.”) (citation omitted). But see Kashner Davidson Sec. Corp. v. Mscisz, 601 F.3d 19, 22 (1st Cir. 2010) (declining to definitively answer the question as to whether manifest disregard had "continued vitality ... . in FAA proceedings").

127. Citigroup Global Mkts., Inc. v. Bacon, 562 F.3d 349, 350 (5th Cir. 2009). 
reaching its decision. ${ }^{128}$ The Citigroup court found that Hall Street unequivocally left the statutory grounds under section 10 as the exclusive avenue to vacatur under the FAA. ${ }^{129}$ Since the Fifth Circuit's precedent had categorized manifest disregard as a non-statutory ground, the court reasoned that it could no longer use manifest disregard as a basis for vacating awards. ${ }^{130}$

In Frazier v. CitiFinancial Corp., the Eleventh Circuit agreed with the Fifth Circuit's Citigroup rationale for discarding manifest disregard. ${ }^{131}$ The Eleventh Circuit affirmed a district court's denial of the plaintiff's motion for vacatur or modification. ${ }^{132}$ On appeal, the plaintiff argued that the district court should not have confirmed the award on the ground that the arbitrator manifestly disregarded the law. ${ }^{133}$ Like the Fifth Circuit before it, the Eleventh Circuit found the language of Hall Street compelling, stating that "our judicially-created bases for vacatur are no longer valid in light of Hall Street." 134

In Medicine Shoppe International, Inc. v. Turner Investments, Inc., the Eighth Circuit became the third of the circuit courts to officially reject the manifest disregard doctrine. Like the Eleventh Circuit in Frazier, the Eighth Circuit affirmed a district court's denial of a motion for vacatur. ${ }^{135}$ The Medicine Shoppe court first held that under Hall Street, courts may vacate arbitral awards only for the reasons outlined in section $10 .{ }^{136}$ Accordingly, the court determined that the ground alleged in the motion for vacatur was not among those listed in $\S 10$ and therefore was not allowable. ${ }^{137}$

\section{Manifest Disregard Survived Hall Street as a Statutory Ground for Vacatur in the Seventh, Second and Ninth Circuits}

Several circuit courts have concluded that manifest disregard survived following the Hall Street decision as a so-called judicial gloss for review

128. Id.

129. Id. at 355.

130. Id.

131. Frazier v. CitiFinancial Corp., 604 F.3d 1313, 1324 (11th Cir. 2010).

132. Id.

133. Id. at 1321 .

134. Id. at 1324

135. Medicine Shoppe Int'l, Inc. v. Turner Invs., Inc., 614 F.3d 485, 488 (8th Cir. 2010).

136. Id. at 489.

137. Id. at 489 . 
under FAA § 10(a). ${ }^{138}$ However, not all of these circuits have come to this conclusion in the same manner. Prior to the decision in Hall Street, the Seventh Circuit had already narrowly tailored its manifest disregard doctrine to fit under section 10(a)(4). Then, after the decision in Hall Street, the Second and Ninth Circuits attempted to accord their pre-Hall Street precedents with the Seventh Circuit's narrowly defined statutory construction of manifest disregard.

1. The Seventh Circuit and Its Pre-Hall Street Statutory Construction

In 2001, the Seventh Circuit decided George Watts \& Son, Inc. v. Tiffany \& Co., in which the court affirmed a district court's denial of a motion for vacatur. ${ }^{139}$ In the decision, Judge Frank Easterbrook questioned whether any overriding principles existed that would authorize courts to review the legal underpinnings - whether written or unwritten - of arbitrators' decisions. ${ }^{140}$ After considering whether manifest disregard could mean something akin to review for clear error, the court determined it could not. ${ }^{141}$ Judge Easterbrook concluded that the "“manifest disregard" principle is limited to two possibilities: an arbitral order requiring the parties to violate the law . . . and an arbitral order that does not adhere to the legal principles specified by contract, and hence unenforceable under [FAA] § 10(a)." ${ }^{142}$ In other words, the Seventh Circuit confined manifest disregard to two specific instances, in which the award contained an inherent bar to enforcement. ${ }^{143}$

Five years later, Judge Posner took the next logical step in Wise $v$. Wachovia Securities $L L C$, affirmatively confining manifest disregard of law to situations which "fit[] comfortably under the first clause of the fourth statutory ground [of $\S 10(\mathrm{a})$ ] — 'where the arbitrators exceeded their powers." 144 By following Judge Easterbrook's language in George Watts, the Wise court differentiated the Seventh Circuit from other circuits that set aside arbitral awards based on a non-statutory approach to manifest disregard. ${ }^{145}$ The court then affirmed the district court's denial of a motion

138. Weston, supra note 105, at 941-42; see Stolt-Nielsen SA v. AnimalFeeds Int'l Corp., 548 F.3d 85, 94 (2d Cir. 2008), rev'd on other grounds, 130 S. Ct. 1758 (2010).

139. George Watts \& Son, Inc. v. Tiffany \& Co., 248 F.3d 577, 581 (7th Cir. 2001).

140. Id. at 579.

141. Id. at 580 .

142. Id. at 581.

143. Id.

144. Wise v. Wachovia Securities LLC, 450 F.3d 265, 268 (7th Cir. 2006).

145. Id. at 268-69. 
[Vol. 13: 325, 2013]

PEPPERDINE DISPUTE RESOLUTION LAW JOURNAL

for vacatur, and Judge Posner directed the parties to the statutory grounds for vacatur as the exclusive grounds for review. ${ }^{146}$

Although some have characterized Wise as embracing a more expansive interpretation of section $10(\mathrm{a})(4),{ }^{147}$ it is more appropriately considered as a narrower conception of manifest disregard, since the Seventh Circuit "confined [manifest disregard] to cases in which arbitrators 'direct the parties to violate the law." "148 In other words, without more than just willful indifference to applicable law present, the Seventh Circuit will not find manifest disregard. ${ }^{149}$ Accordingly, the Seventh Circuit became the first of the circuit courts to limit manifest disregard to a statutory ground under section 10(a)(4). ${ }^{150}$

\section{The Second and Ninth Circuits' Post-Hall Street Rebranding of Manifest Disregard}

Following the Supreme Court's language regarding manifest disregard in Hall Street, two circuit courts agreed at least nominally with the approach of the Seventh Circuit and attempted to fit their manifest disregard doctrines under the statutory umbrella. Namely, the Second and Ninth Circuits have asserted that manifest disregard survived Hall Street as shorthand for analysis under section 10(a)(4). ${ }^{151}$

In Stolt-Nielsen SA v. AnimalFeeds International Corp., the Second Circuit held that Hall Street "did not . . . abrogate the 'manifest disregard' doctrine altogether." ${ }^{\text {"152 }}$ Where the arbitrator had permitted class arbitration despite the arbitration agreement's silence on the matter, the district court vacated the award because the arbitrator did not perform a meaningful

146. Id. at 269.

147. Sims \& Bales, supra note 84, at 427 (internal quotations omitted).

148. Wise, 450 F.3d at 269 (quoting George Watts \& Son, Inc. v. Tiffany \& Co., 248 F.3d 577, 580 (7th Cir. 2001)) (emphasis added).

149. Aragaki, supra note 4, at 12 .

150. See Aragaki, supra note 4, at 4 n.25 ("Even prior to Hall Street, the Seventh Circuit had reinterpreted manifest disregard as a statutory, rather than a common law, doctrine.") (citing George Watts, 248 F.3d at 581); Sims \& Bales, supra note 84, at 427 ("The Seventh Circuit is the only circuit that did not view manifest disregard as a non-statutory ground for review prior to Hall Street.").

151. Berger \& Sun, supra note 3, at 777.

152. Stolt-Nielsen SA v. AnimalFeeds Int'l Corp., 548 F.3d 85, 95 (2d Cir. 2008), rev'd on other grounds, 130 S. Ct. 1758 (2010).

345 
choice-of-law analysis. ${ }^{153}$ Agreeing in principle with the Seventh Circuit's approach to manifest disregard, the Stolt-Nielsen court reversed the district court's vacatur. ${ }^{154}$

The Second Circuit laid out its new statutory conception of manifest disregard as a sort of progeny of the Seventh Circuit's, in which the court bore a responsibility to vacate awards in which the arbitrator "willfully flouted the governing law by refusing to apply it." 155 In this situation, the court reasoned, the arbitrators did not interpret the contract at all and thereby exceeded their powers under section 10(a)(4). ${ }^{156}$ The crux of the court's argument revolved around the assertion that "parties do not agree in advance to submit to arbitration that is carried out in manifest disregard of the law." "157 Accordingly, manifest disregard review has maintained a continued viability in the Second Circuit.

Similarly, in Comedy Club, Inc. v. Improv West Associates, ${ }^{158}$ the Ninth Circuit adopted a corresponding approach, stating that Hall Street did not undermine prior precedent, and as a result, manifest disregard retains continued validity as a ground for vacatur under section 10(a)(4). ${ }^{159}$ Not wholly dissimilar to Hall Street, Comedy Club involved a complicated procedural history, including vacation and remand by the Supreme Court for a decision in accordance with Hall Street. ${ }^{160}$ The Comedy Club court vacated part of a district court's order confirming an arbitral award. ${ }^{161}$

Reasoning that the arbitrator had neither the power to bind nonparties to the agreement by a permanent injunction nor to enforce a nationwide in-term covenant not to compete - both in "manifest disregard" of California Business and Professions Code (CBPC) section 16600 - the Ninth Circuit held that the arbitrator exceeded his power under section 10(a)(4). ${ }^{162}$

Consequently, like the Second Circuit, manifest disregard review continues in the Ninth Circuit through a nomenclature of statutory construction.

153. Id. at 89-90 (quoting Stolt-Nielsen SA v. AnimalFeeds Int'l Corp., 435 F. Supp. 2d 382, 385 (S.D.N.Y. 2006)).

154. Id. at 95.

155. Id. (quoting Westerbeke Corp. v. Daihatsu Motor Co., 304 F.3d 200, 217 (2d Cir. 2002)).

156. Id.

157. Id.

158. Comedy Club, 553 F.3d 1277 (9th Cir. 2009).

159. Id. at 1281 .

160. Id.

161. Id.

162. Id. at 1287-94. 
[Vol. 13: 325, 2013]

PEPPERDINE DISPUTE RESOLUTION LAW JOURNAL

\section{Manifest Disregard Lingers as a Nonstatutory Ground for Vacatur in the Sixth Circuit}

In Coffee Beanery, Ltd. v. WW, L.L.C., ${ }^{163}$ an unpublished opinion decided in 2008, the Sixth Circuit left its pre-Hall Street precedent "untouched." "164 In order to do so, the Coffee Beanery court narrowly construed the holding in Hall Street, stating that the decision did not foreclose judicial review for arbitral manifest disregard. ${ }^{165}$ Reasoning that because the Supreme Court failed to definitively resolve Wilko's meaning, the Court's holding pertained only to contractual supplements by private parties. ${ }^{166}$ As a result, the Sixth Circuit vacated the award because the arbitrator did not apply a Maryland franchise law in a dispute arising out of a franchise agreement. ${ }^{167}$ The franchise law had required the disclosure of a specific class of felony convictions. ${ }^{168}$ However, the arbitrator concluded that the franchisor's failure to disclose a grand larceny conviction was immaterial because the franchise law did not contemplate that particular felony. ${ }^{169}$ The court disagreed, finding that the award displayed the arbitrator's manifest disregard of applicable law. ${ }^{170}$

This case is reminiscent of the tension between an arbitrator merely misinterpreting a law or manifestly disregarding it. ${ }^{171}$ On the one hand, the arbitrator interpreted that the felony was not of the variety contemplated by the statute's disclosure requirement. ${ }^{172}$ On the other, as the Sixth Circuit pointed out, the arbitrator probably should have found the failure to disclose material, since the statute required the disclosure of "any person identified in

163. 300 F. App 415 (6th Cir. 2008).

164. Annie Chen, Note, The Doctrine of Manifest Disregard of the Law after Hall Street: Implications for Judicial Review of International Arbitrations in U.S. Courts, 32 FORDHAM INT'L L.J. 1872, 1892 (2009); see Coffee Beanery, 300 F. App at 419 (“[T]his Court will follow its wellestablished precedent here and continue to employ the 'manifest disregard' standard."). In a subsequent decision, the Sixth Circuit has apparently "retreated" slightly from its conclusion in Coffee Beanery. Aragaki, supra note 44, at 5 n.33. See Grain v. Trinity Health, Mercy Health Servs., Inc., 551 F.3d 374, 380 (6th Cir. 2008).

165. Coffee Beanery, 300 F. App at 418.

166. Id. at $418-19$.

167. Id. at 421.

168. Id. at 420 .

169. Id.

170. Id. at 419.

171. See supra Part I.C.

172. Coffee Beanery, 300 F. App at 420. 
the prospectus [who] has been convicted of a felony ... . if the felony or civil action involved fraud, embezzlement, fraudulent conversion, or misappropriation of property." 173 Grand larceny certainly qualifies as a misappropriation of property. ${ }^{174}$ Regardless, the tension persists because, as Judge Oakes presciently stated, “one man's ‘interpretation' may be another's 'disregard." "175

\section{RESOLVING THE SPLIT}

In order to resolve the split, the Court can consider doing two things. First, siding with the circuits that have already discarded manifest disregard, the doctrine should officially be abolished, and the contents of section 10 should be recognized as the exclusive grounds for vacatur under the FAA. Second, by reconceptualizing "final" as it appears in section 10(a)(4), lower courts will have the tools to review arbitral awards while expressly abstaining from a de novo review on the merits. This method allows courts to review arbitral awards following the text of the FAA without disturbing the integrity of the benefit of the arbitration bargain.

\section{A. Manifest Disregard Does Not "Fit" Under the FAA}

Examining the history of the FAA, it becomes clear that the drafters never envisioned the enforcement of illegal or unconscionable awards. ${ }^{176}$

Over time, however, this understanding has eroded, and courts have sought increasing supervision of the arbitral process. ${ }^{177}$ As Professor Carbonneau notes, pressure to change the arbitral process and provide greater protection to individual rights has led to a variety of nonstatutory and common law grounds for vacatur, including the use of unconscionability, actions to clarify awards, and contract provisions that allow enhanced judicial review. ${ }^{178}$

Among common law grounds, the ambiguous and subjective manifest disregard standard provides another potential for review that the drafters of

173. Id. (quoting MD. CODE ANN. Bus. ReG. § 14-216(8)(i)).

174. Id. (quoting MD. CODE ANN. Bus. REG. § 14-216(8)(i)).

175. I/S Stavborg v. Nat'1 Metal Converters, Inc., 500 F.2d 424, 430 n.13 (2d Cir. 1974).

176. See Joint Hearings, supra note 56, at 36 ("The courts are bound to accept and enforce the award of the arbitrators unless there is in it a defect so inherently vicious that, as a matter of common morality, it ought not to be enforced."); Cohen \& Dayton, supra note 20, at 273. While the legislative history of the FAA is admittedly limited in scope, this language clearly indicates that the statute never envisioned the enforcement of illegal awards or awards that might shock the conscience.

177. Carbonneau, supra note 55, at 241-42.

178. Id. 
[Vol. 13: 325, 2013]

PEPPERDINE DISPUTE RESOLUTION LAW JOURNAL

the FAA did not envision - a technical review of arbitral awards on their merits. ${ }^{179}$ Congress enacted the FAA to abrogate the old common law doctrines hostile to arbitration agreements; manifest disregard should likewise be invalidated as a remnant of the same ancient judicial hostility. ${ }^{180}$

To begin with, as illustrated above, manifest disregard as a nonstatutory ground for vacatur obviates the bargained-for benefits of an arbitration agreement. ${ }^{181}$ If manifest disregard survived Hall Street as such, then the doctrine should be abolished on these grounds alone. However, if "manifest disregard" is now simply shorthand for analysis under FAA § 10(a)(4) then it is confusing and unnecessary. Judge Posner made just this point in Baravati: "If [manifest disregard] is intended to be synonymous with the statutory formula that it most nearly resembles . . . it is superfluous and confusing. There is enough confusion in the law. The grounds for setting aside arbitration awards are exhaustively stated in the statute." ${ }^{, 182}$ Indeed, the ambiguity and confusion inherent in any manifest disregard analysis means that the terms' use alone creates the possibility for "back door" review of arbitral awards on their merits. ${ }^{183}$

Next, manifest disregard as defined by the Second Circuit in StoltNielsen and the Ninth Circuit in Comedy Club does not meet the definition of arbitral excess of authority under FAA section 10(a)(4). Under the traditional definition, arbitrators exceed their powers when they decide issues not submitted to arbitration or when the arbitrators decline to follow principles of adjudication set out in the agreement to arbitrate. ${ }^{184}$ In 2011,

179. Joint Hearings, supra note 56, at 36 ("There is no authority and no opportunity for the court, in connection with the award, to inject its own ideas of what the award should have been."); Cohen \& Dayton, supra note 20, at 273 (same); but cf. id. (emphasizing the importance of courts "refus[ing] to permit the invasion of technicalities in the application of the law or the determination of rights under it").

180. Reuben, supra note 3, at 1110.

181. See supra Parts I.A, C

182. Baravati v. Josephthal, Lyon \& Ross, Inc., 28 F.3d 704, 706 (7th Cir. 1994).

183. For this reason, statements which include manifest disregard as a tool to enforce arbitration agreements rather than review them should be viewed with skepticism. See, e.g., Wachovia Sec., LLC v. Brand, No. 10-2111, 2012 WL 507022, at *8 (4th Cir. Feb. 16, 2012) ("Whether manifest disregard is a "judicial gloss" or an independent ground for vacatur, it is not an invitation to review the merits of the underlying arbitration.”); Stolt-Nielsen S.A. v. AnimalFeeds Int'l Corp., 548 F.3d 85, 95 (2d Cir. 2009) (“[W]e view the 'manifest disregard' doctrine, and the FAA itself, as a mechanism to enforce the parties' agreements to arbitrate rather than as judicial review of the arbitrators' decision.")

184. Citigroup Global Mkts., Inc. v. Bacon, 562 F.3d 349, 351 (5th Cir. 2009); Hayford, supra note 2, at 455-56; Reuben, supra note 3, at 1109 ("Arbitrators exceed their powers when they issue 
the Second Circuit defined arbitral excess of authority along these traditional lines in Jock $v$. Sterling Jewelers Inc, ${ }^{185}$ stating that "an arbitrator may exceed her authority by, first, considering issues beyond those the parties have submitted for her consideration, or, second, reaching issues clearly prohibited by law or by the terms of the parties' agreement."186

Additionally, an excess of arbitral power occurs when an arbitrator or tribunal is not constituted in accordance to the terms of the arbitration agreement. ${ }^{187}$ Since arbitration depends on party consent through the arbitration agreement, parties confer the power to settle disputes through the terms of their agreement. ${ }^{188}$ When the appointment of an arbitrator or tribunal does not follow these terms, decision-making power does not confer upon the arbitral tribunal. ${ }^{189}$ Accordingly, although an arbitrator may determine certain issues that affect the arbitrator's power to make an award, ${ }^{190}$ an award will not be enforced if the arbitrator's selection does not follow the parties' agreed-upon method. ${ }^{191}$ Where the parties have not conferred the power to enter an award, the pure act of rendering one exceeds the arbitrator's powers.

Accepting these definitions, a problem pervades the Second and Ninth Circuits' conceptualizations of excess of authority. Namely, manifest disregard situations often involve the decision of either a properly appointed or constituted arbitrator or tribunal in which the award expressly confines itself to the issues submitted by the parties. For example, in Comedy Club the Ninth Circuit vacated an award on the basis of manifest disregard where

an award on an issue not presented to them in the submission to arbitration, or when they fail to adhere to other constraining criteria prescribed by the parties, such as arbitration rules that the parties may have drafted into their arbitration provisions ...."); accord H. ARTHUR DUNN \& HENRY P. Dimond, Commercial ARbitration: Being a Compilation of AWARds of ARBitration COMMITTEes of VARIOUS TRADE AsSOCIATIONS AND CHAMBERS OF COMMERCE IN THE UNITED STATES 20 (1922) ("The submission [to arbitration] creates the special jurisdiction of the arbitrators, and the award necessarily must conform thereto, else it not be considered valid.").

185. 646 F.3d 113 (2d Cir. 2011).

186. Id. at 122.

187. See Encyclopaedia Universalis S.A. v. Encyclopaedia Britannica, Inc., 403 F.3d 85, 92 (2d Cir. 2005) ("Under the FAA, an award issued by arbitrators who are not appointed in accordance with agreed-upon procedures may be vacated because the arbitrators 'exceeded their powers."').

188. Avis Rent A Car Sys., Inc. v. Garage Employees Union, Local 272, 791 F.2d 22, 25 (2d Cir. 1986).

189. Id. ("The defect in the method used to select [the arbitrator] left him powerless to implement the ... Agreement.").

190. An example of such a situation includes the doctrine of kompetenz-kompetenz, under which an arbitrator or tribunal has the ability or "competence" to determine its own jurisdiction. See Natasha Wyss, Note, First Options of Chicago, Inc. v. Kaplan: A Perilous Approach to KompetenzKompetenz, 72 TuL. L. REV. 351, 352-53 (1997). Cir.1977))

191. 72 TuL. L. Rev. 351, 352-53 (1997) (citing Tamari v. Conrad, 552 F.2d 778, 781 (7th 
[Vol. 13: 325, 2013]

PEPPERDINE DISPUTE RESOLUTION LAW JOURNAL

the award resolved only issues submitted to the arbitrator. ${ }^{192}$ The Comedy Club court vacated on the ground that the arbitrator exceeded his power by enjoining nonparties to the agreement and enforcing an overly broad in-term covenant not to compete. ${ }^{193}$ However, the arbitrator bound nonparties to the agreement by employing the term "affiliate" as defined in the underlying contract and enforcing the covenant as found in the contract. ${ }^{194}$ Where an award uses the contract's definition of a term and enforces a covenant as it appears in the contract, both on issues submitted for determination, the arbitrator has by definition remained within his or her delegated authority under the arbitration agreement. ${ }^{195}$

The Second Circuit attempted to correct this inconsistency when it asserted that, "[P]arties do not agree in advance to submit to arbitration that is carried out in manifest disregard of the law." ${ }^{196}$ This assertion seems to discount the reality that any error of law could potentially be deemed manifest disregard, since litigants will never expressly grant an arbitrator the power to make a mistake. ${ }^{197}$ The court simply ignores the fact that the parties delegated the authority to decide the case to an arbitrator rather than a judge, and as such, the parties have assumed the risk that the arbitrator might decide incorrectly. ${ }^{198}$ In addition, as frequently occurs, "submissions to arbitration ... do not call for the arbitrator to apply [a specific] law."199

Within the context of these "general" submissions to arbitration, the Second Circuit's own Jock definition of excess of authority undermines its

192. Comedy Club, Inc. v. Improv West Assocs., 553 F.3d 1277, 1287-94 (9th Cir. 2009); see supra Part II.C.2.

193. Comedy Club, 553 F.3d at 1283.

194. Id. at 1286-89.

195. See United Paperworkers Int'l Union v. Misco, 484 U.S. 29, 38 (1987) (“As long as the arbitrator is even arguably construing or applying the contract and acting within the scope of his authority, that a court is convinced he committed serious errors does not suffice to overturn his decision."); but cf. Reuben, supra note 3, at 1109 ("For cases in which the decision is not drawn from the essence of the contract, Section 10(a)(4) provides an adequate remedy-not because the awards are . . . irrational, but because they exceed the scope of the authority's authority since the award is not drawn from the essence of the contract that the arbitrator has been authorized to interpret by the parties.").

196. Stolt-Nielsen SA v. AnimalFeeds Int'l Corp., 548 F.3d 85, 95 (2d Cir. 2008), rev'd on other grounds, 130 S. Ct. 1758 (2010).

197. William W. Park, The Four Musketeers of Arbitral Duty, in Is ARBITRATION ONLY As Good As the Arbitrator? Status, Powers and Role of the Arbitrator 33 (ICC Dossiers, Vol. 8 No. 1, 2011)

198. Park, supra note 188.

199. Reuben, supra note 3, at 1147.

351 
Stolt-Nielsen argument that parties do not agree in advance to manifest disregard. When parties do not specify a law to which the arbitral analysis must adhere, arbitrators may commit errors of law without rendering a decision unauthorized by the parties, so long as the arbitrators only decide issues submitted to them. ${ }^{200}$ In such a situation, the arbitrators have not exceeded their authority to make the determination. ${ }^{201}$ Professor Reuben takes this point one step further:

Because the arbitrator is not required to follow the law, it makes little sense to evaluate the arbitrator's decision on the basis of how well it complies with the law. Indeed, if the arbitral decision is not based on law and is instead based on some other norm, such as industry custom or practice, manifest disregard effectively constitutes a substitution of judgment by the court for the decision of the arbitrator. ${ }^{202}$

By holding an arbitrator to a legal construction where the parties have not specified these or any other guidelines in their agreement, courts effectively vitiate the arbitrator's bargained-for determination. ${ }^{203}$

As a result, review for manifest disregard of law does not fit into FAA section 10(a)(4) review for an arbitrator's excess of authority. ${ }^{204}$

Additionally, these courts have not in reality changed their manifest disregard analysis to adapt to the new statutory configuration under section 10(a)(4). ${ }^{205}$ Scholars and practitioners alike have found this doctrinal approach troubling. ${ }^{206}$ Affixing the label "dog" to a cat does not suddenly make the animal a canine.

Furthermore, looking at section 10(a)(4) from a "textualist" approach, the subsection differentiates between arbitrators "exceed[ing] their powers" and arbitrators "imperfectly execut[ing]" those powers. ${ }^{207}$ By separating these two possible rationales with a comma and "or," the statute makes clear

200. Jock v. Sterling Jewelers Inc., 646 F.3d 113, 123 (2d Cir. 2011).

201. Id.

202. Reuben, supra note 3, at 1149.

203. Cf. id. at 1147 ("Manifest disregard has no place in the modern structure of arbitration for general submissions to arbitration ....”).

204. Aragaki, supra note 4, at 10; Reuben, supra note 3, at 1144 ("[M] anifest disregard review should not be viewed as synonymous with exceeding-power review.”).

205. See supra Part II.C.2.

206. See e.g., Aragaki, supra note 4, at 10 (“[T] complications. One such complication may arise because courts have largely continued to use preHall Street manifest disregard precedents without questioning whether they are appropriate in a statutory manifest disregard regime."); Christopher Walsh, Stolt-Nielsen's Comfort for the "Average Arbitrator": An Analysis of the Post-Hall Street "Manifest Disregard" Award Review Standard, 27 Alternatives to High Cost Litig. 19, 21 (2009) (finding it "troubling" that "the Second Circuit continues to apply the doctrine as it was developed before Hall Street when it was considered by the Second Circuit to be an extrastatutory basis for vacatur").

207. 9 U.S.C. § 10(a)(4) (2006).

352 
[Vol. 13: 325, 2013]

PEPPERDINE DISPUTE RESOLUTION LAW JOURNAL

that the grounds exist distinct from one another. ${ }^{208}$ The Second Circuit's attempt to grandfather its pre-Hall Street manifest disregard law into a postHall Street statutory regime improperly combines the two distinct grounds, further perpetuating the confused and muddled conception of vacatur under section 10(a)(4). Accordingly, in the words of Professor Reuben, "the ghost of manifest disregard" should be laid to rest. ${ }^{209}$

\section{B. Reconceptualizing a "Final” Award Under Section 10(a)(4)}

The traditional views of the finality of arbitral awards fall short of the fundamental nature of arbitration, finality as interpreted in the international context, and the intentions of the FAA's drafters. ${ }^{210}$ Consequently, courts have sought to expand and define their roles in policing arbitral awards through means such as manifest disregard of the law. ${ }^{211}$ This reconceptualization seeks to remedy the shortcomings by envisioning a twostep process. First, enforceability must be considered as a criteria of a "final" award under section 10(a)(4). ${ }^{212}$ Next, the use of section 11(c) should be expanded to include instances where a court determines that an award does not meet the requirement of enforceability, but modifying the terms of the award will not disturb its merits. By reconceptualizing the procedure for enforcing and modifying awards, courts will have at least the superficial control over arbitral awards they crave, but in a manner that excludes reviewing the merits of the decision.

\section{A "Final” Award Under Section 10(a)(4) Must Be Enforceable}

FAA section 10(a)(4) allows courts to vacate an arbitral award "[w]here the arbitrators exceeded their powers, or so imperfectly executed them that a mutual, final, and definite award upon the subject matter submitted was not

208. Id.; accord Cohen \& Dayton, supra note 20, at 268 ("[I]f [the arbitrators] exceeded their powers or failed to make a mutual, final or definite award, then and then only the award may be vacated.") (emphasis added).

209. Reuben, supra note 3, at 1146.

210. See supra notes 15-17 and accompanying text; see infra Parts I.C \& III.B.1.

211. See supra Part I.D.

212. Such a construction simply reflects the Supreme Court's pronouncement that, "[t]he federal [arbitration] policy is simply to ensure the enforceability, according to their terms, of private agreements to arbitrate.” Volt Info. Scis., Inc. v. Bd. of Trs. of Leland Stanford Junior Univ., 489 U.S. 468, 476 (1989). After all, "[t] the private practice of arbitration [is] of little practical use without the authority of court enforcement ...." Berger \& Sun, supra note 3, at 748. 
made." "213 As mentioned, the traditional conceptualization of a "final" award under this section has remained largely procedural in nature. ${ }^{214}$

Reconceptualization does not seek to change that. Instead, it seeks to expand the traditional concept to include and implement the words of Julius Henry Cohen, one of the principal drafters of the FAA, when he stated, "[t]he judgment so entered [under FAA section 9] is subject to the same provisions of law as any other judgment, whether as to enforcement, appeal therefrom, or in any other respect." ${ }^{, 15}$ In other words, in order for an arbitral award to be considered "final" under section 10(a)(4), the award must be enforceable in the same manner as any public judgment.

As previously noted, the drafters of the FAA did not consider the possibility that courts would enforce illegal or immoral arbitral awards under the putative authority of the FAA. ${ }^{216}$ Under this reconceptualization, if a court cannot enforce an arbitral award on the ground that the award itself violates a law, the award is not final; if a court refuses to enforce an award on other public policy grounds, the award is not final. ${ }^{217}$ By adding "enforceability" to the traditional conceptualization of "final," the Seventh Circuit's definition of manifest disregard fits nicely under section 10(a)(4) without requiring the confused designation of manifest disregard as shorthand or judicial gloss. Thus, courts will put into effect Judge Posner's

213. 9 U.S.C. § 10(a)(4) (2006).

214. See supra note 69 and accompanying text (describing that the parties' dispute must be resolved to such an extent that they need not litigate further to finalize their obligations). Additionally, judicial interpretation of "final" has been said to track the "final judgment rule," which denies appellate review of interlocutory appeals. Jennifer M. Rhodes, Judicial Review of Partial Arbitral Awards Under Section 10(a)(4) of the Federal Arbitration Act, 70 U. CHI. L. REv. 663, 664 (2003). For a broad examination and discussion of judicial interpretation of section 10(a)(4) "final" paralleling the final judgment rule, see generally id.

215. Cohen \& Dayton, supra note 20, at 269 (emphasis added).

216. See Joint Hearings, supra note 56, at 36 ("The courts are bound to accept and enforce the award of the arbitrators unless there is in it a defect so inherently vicious that, as a matter of common morality, it ought not to be enforced."); Cohen \& Dayton, supra note 20, at 273 (same).

217. For examples of arbitral awards which courts do not enforce on public policy grounds, see Reuben, supra note 3, at 1141-43. Professor Reuben argues for the elimination all nonstatutory or common law grounds for vacatur except for those awards vacated on public policy grounds. Reuben, supra note 3. The argument for the continued viability of a public policy exception to § 10(a)'s exclusivity sounds remarkably similar to the Seventh Circuit's narrow statutory definition of manifest disregard of the law. Compare Wise v. Wachovia Sec., LLC, 450 F.3d 265 (7th Cir. 2006) (confining manifest disregard to "cases in which arbitrators "direct the parties to violate the law") (quoting George Watts \& Son, Inc. v. Tiffany \& Co., 248 F.3d 577, 580 (7th Cir. 2001)), with Reuben, supra note 3, at 1141-43 ("It seems likely that courts will recognize a public policy exception to the seemingly strict rule of Hall Street, at least for illegal arbitration awards."). The argument for reconceptualization of what constitutes a final award under section 10(a)(4) encompasses both Professor Reuben's exception and the Seventh Circuit's manifest disregard model, making the need for either designation unnecessary.

354 
[Vol. 13: 325, 2013]

PEPPERDINE DISPUTE RESOLUTION LAW JOURNAL

admonition that "[w]e can understand neither the need for the [manifest disregard] formula nor the role that it plays in judicial review of arbitration (we suspect none - that it is just words)."218

2. Section 11(c) as a Tool to Enable Courts to Effect Arbitral Intent and Promote Justice Among the Parties

In instances where courts find arbitral awards unenforceable, the courts should have greater leeway to modify the award to make it enforceable. Courts should employ this authority under FAA section 11(c) as long as the modification does not affect the merits of the award. ${ }^{219}$ The argument that courts should utilize section 11 in conjunction with section 10 finds support in two places. One, the language of both the first and second grounds for vacatur under section 10(a)(4) relate to and parallel sections 11(b) and (c), respectively. ${ }^{220}$ Two, the language of section 11 clearly voices its support for this proposition.

The language of sections 10(a)(4) and 11 parallel each other in two ways. First, section 10(a)(4)'s reference to an arbitrator's excess of authority relates directly to authorization of a court to modify under section 11(b), in which the arbitrators have decided a matter not in the submission to arbitration. ${ }^{221}$ Although section 11(b) does not use the terms "exceeded their powers" or similar constructions, the section nonetheless employs the traditional definition of arbitral excess of authority. ${ }^{222}$ Second, sections 10(a)(4) and 11(c) refer to "imperfect[] execut[ion]" and an arbitral award as being "imperfect in matter of form" as grounds for vacatur and modification, respectively. ${ }^{223}$ The parallel of both language and concepts between these subsections supports their contemplated use in conjunction

218. Baravati v. Josephthal, Lyon \& Ross, Inc., 28 F.3d 704, 706 (7th Cir. 1994).

219. FAA section 11 (c) allows for an order modifying or correcting an award "[w]here the award is imperfect in matter of form not affecting the merits of the controversy." 9 U.S.C. § 11(c) (2006).

220. See supra notes 207-209 and accompanying text (describing separate grounds for vacatur as flowing from two distinct clauses under section 10(a)(4)).

221. Compare 9 U.S.C. § 10(a)(4) (authorizing vacatur "where the arbitrators exceeded their powers"), with 9 U.S.C. § 11(b) (authorizing modification "[w]here the arbitrators have awarded upon a matter not submitted to them").

222. See supra note 184 and accompanying text (describing the traditional definition of arbitrators exceeding their power as arbitrators issuing awards on issues not submitted for determination, or arbitrators failing to follow other constraining criteria prescribed by the parties).

223. 9 U.S.C. $\S \S 10(a)(4), 11(c)$. 
with one another, or, at worst, that the two sections are not incompatible with one another.

Defining the FAA section's impetus, section 11 states that the court may make an order to "modify and correct the award, so as to effect the intent thereof and promote justice between the parties."224 Julius Henry Cohen echoed this sentiment, reaffirming its importance within the context of section $11 .{ }^{225}$ Accordingly, courts should utilize section 11 - and subsection 11(c) in particular - as a tool to effect the award's intent, rather than simply as a means to correct typos and miscalculations. ${ }^{226}$

The argument for expanded use of section 11(c) as a tool should not extend beyond modifications a court can make without affecting the merits of the award. As such, a court should look only to the award itself to determine (1) the award's finality (enforceability) and, (2) only where necessary, whether modification will not affect the merits of the decision. To accomplish this task, judicial modification made under section 11 should not extend beyond accepted contract interpretation techniques.

Judges interpret a multitude of contracts. ${ }^{227}$ There is no reason to believe they could not apply the same accepted contract interpretation techniques to successfully modify awards without delving into the merits of the matter. ${ }^{228}$ Such methodology would be analogous to the FAA's pronouncement in section 2 that arbitration agreements "shall be valid, irrevocable, and enforceable, save upon such grounds as exist at law or in

224. 9 U.S.C. $\S 11$.

225. See Cohen \& Dayton, supra note 20, at 273 ("Correction or modification is so to be made as to effect the intent of the award and to promote justice.").

226. Many courts have relegated FAA section 11 to the status of spell-check or calculator, correcting miscalculations and other readily apparent errors under the authority of $\S 11(a)$. See CARBONNEAU, supra note 9, at 81 ("Under Section Eleven, U.S. federal courts, upon the request of one of the parties, have the power to modify or correct awards for inadvertent technical errors that might preclude enforcement ... The errors in question must be 'evident' and unrelated to the merits of the determination. The provision has not become a source of litigious obfuscation.").

227. See, e.g., Steven Shavell, On the Writing and Interpretation of Contracts, 22 J. L. ECON. \& ORG. 289, 290 (2005) ("We . . observe that the courts actively engage in the interpretation of contracts. The courts fill gaps in contracts, resolve conflicts and ambiguities in language, and sometimes replace the parties' express terms (such as to permit substitution of material B if a problem with A occurs).") (citation omitted).

228. See Randall H. Warner, All Mixed Up About Contract: When Is Contract Interpretation a Legal Question and When Is It a Fact Question?, 5 VA. L. \& BUS. REV. 81, 85-86 (2010) (describing two different traditions for contract interpretation, the "traditional" view-where "there was ... a notion that deciphering language was a lawyerly function" - and the "modern" view - held as a "quest to determine what the parties intended"). Under the traditional view of contract interpretation, analogous to the task of statutory interpretation, the legal question is that of construing language. Id. at 84 . It is within this context that federal judges - who are well-versed in contract interpretation - should modify otherwise unenforceable awards and bring them within the realm of enforceability.

356 
[Vol. 13: 325, 2013]

PEPPERDINE DISPUTE RESOLUTION LAW JOURNAL

equity for the revocation of any contract." ${ }^{\text {229 }}$ Doing so would keep any judicial frolicking to a minimum and within section 11's stated goal of achieving the parties' intent and promoting justice between them. ${ }^{230}$ This approach also accords with Cohen's statements that section 11 allows "no opportunity for technical procedure."231 Furthermore, this approach does not run afoul of functus officio as the award never returns to the arbitrators, while at the same time bearing a striking resemblance to the exceptions already carved out of that doctrine. ${ }^{232}$ By allowing a judge to simply look to the award to determine its enforceability, thereby removing the need to remand awards back to arbitration for further proceedings, the solution plainly promotes efficiency in the total arbitration process.

The decision in Comedy Club provides the perfect opportunity to reconceptualize an analysis under FAA sections 10(a)(4) and 11(c) as well as to clarify the Ninth Circuit's attempt to shoehorn pre-Hall Street manifest disregard doctrine into a purported statutory construction.

\section{Resolution in Practice - Comedy Club Reconceptualized}

In deciding Comedy Club, Inc. v. Improv West Associates, the Ninth Circuit made two major findings that affected the award at issue in the case. First, the court determined that the arbitrator exceeded the scope of his authority by enjoining nonparties to the agreement. ${ }^{233}$ Next, the court found that the arbitrator exceeded the scope of his authority by enforcing an interm covenant not to compete over an excessively broad area of land. ${ }^{234}$ As previously noted, however, it is problematic to state that the arbitrator exceeded his authority in this situation. ${ }^{235}$ In actuality, the arbitrator confined his decision to the express terms of the contract by issuing an injunction with the term "affiliate" as defined in the contract, and enforcing as drafted the contractual in-term covenant not to compete. ${ }^{236}$

229. 9 U.S.C. § 2.

230. 9 U.S.C. $\S 11$

231. Cohen \& Dayton, supra note 20, at 273 (“[I]n no case do [the provisions of § 11] act as a bar to informal and expert determination of the matter.").

232. See infra Part I.C.

233. Comedy Club, Inc. v. Improv West Assocs., 553 F.3d 1277, 1283 (9th Cir. 2009).

234. Id. at 1293

235. See supra Part III.A.

236. Comedy Club, 553 F.3d at 1286-89 (The decision finds fault with the arbitral award on the basis of the arbitrator's use of the term "affiliate" as defined in the contract, explaining the arbitrator's decision as "keeping in force the restrictive covenant" as drafted in the contract). 
Another inherent problem with the Comedy Club decision involves the procedural characterization by which the court purported to act. Though the Ninth Circuit claimed to vacate on grounds of manifest disregard, the court then remanded to the district court with instructions to immediately reinstate the award, albeit in a diluted form. ${ }^{237}$ Read in this light, it appears the Ninth Circuit in fact modified rather than vacated the award. As such, the court should have looked to section 11 rather than the post-Hall Street, section 10(a)(4) version of manifest disregard upon which it relied. ${ }^{238}$

Reconceptualization under section 10(a)(4) is superior to the Ninth Circuit's construction because it remains faithful to the parties' bargain and refrains from arbitrarily substituting a court's opinion for an arbitrator's. Additionally, reconceptualization would have required the court to conduct a narrower review than what actually occurred and left the merits of the decision undisturbed. By examining the award alone, the court cannot expand the scope of its review to include a full review on the merits "smuggle[d] . . . in by the back door." 239

\section{Step One: Determining the Award's Finality (Enforceability)}

To begin with, the Ninth Circuit did not, and should not have concluded that the arbitrator exceeded his authority by issuing a permanent injunction. ${ }^{240}$ Instead, the offense related to the scope of the permanent injunction. ${ }^{241}$ Accordingly, the court should have simply concluded that because the contract's definition of the term "affiliate" violated CBPC section 16600, the award was unenforceable as written. Next, the Ninth Circuit should not have described its decision to limit the in-term covenant not to compete as a vacatur on the ground that the arbitrator exceeded his power by manifestly disregarding CBPC section $16600 .{ }^{242}$ Instead, the court should have followed an almost identical reconceptualized vacatur analysis as with the permanent injunction. Since the breadth of the in-term covenant not to compete violated CBPC section 16600 , the court simply could not

237. See id. at 1294 ("We vacate the district court's order confirming the arbitration award and remand to the district court with instructions to vacate the Partial Final Arbitration Award in so far as it enjoins CCI's Affiliates, unless they are agents or otherwise acting for CCI, and to the extent it prevents CCI from opening or operating non-Improv clubs in counties in which CCI does not now operate or own an Improv club.").

238. Id. at 1289-94.

239. Baravati v. Josephthal, Lyon \& Ross, Inc., 28 F.3d 704, 706 (7th Cir. 1994).

240. Comedy Club, 553 F.3d at 1286.

241. Id.

242. Id. at 1293. 
[Vol. 13: 325, 2013]

PEPPERDINE DISPUTE RESOLUTION LAW JOURNAL

enforce the award. ${ }^{243}$ By finding the award unenforceable, the court would have thereby determined that the arbitrators imperfectly executed their powers by not issuing a final and definite award. ${ }^{244}$

\section{Step Two: Modifying the Award}

Finding the award unenforceable and therefore not final, the court would have then moved on to step two of the reconceptualized analysis. In this step, the court would have asked: was the award "imperfect in matter of form not affecting the merits of the controversy"? ${ }^{245}$ Since the first issue that the Ninth Circuit found offensive in the award amounted to the excessive scope of a single defined term, ${ }^{246}$ the court likely would have answered in the affirmative. In its decision, the Comedy Club court essentially employed a blue-pencil test ${ }^{247}$ editing the definition of "affiliate" by striking out the definition's overreaching portion so that it conformed to the standards of section 16600 of California Business and Profession Code. ${ }^{248}$ The blue-pencil test falls within the category of equitable contract interpretation and construction techniques discussed previously as a method to limit ambiguity and potential judicial frolicking. ${ }^{249}$

Next, the court would have asked: was the award as it related to the second issue - the overly broad in-term covenant not to compete"imperfect in matter of form not affecting the merits of the controversy"? Since a simple modification of the in-term covenant not to compete effected the intent of the award and promoted justice without affecting the merits, the court likely would have again answered in the affirmative. Analogous to the use of the blue-pencil test on the preceding definition, the Comedy Club

243. Id.

244. 9 U.S.C. $\S 10(a)(4)(2006)$.

245. 9 U.S.C. $\S 11(\mathrm{c})$.

246. See Comedy Club, 553 F.3d at 1286 ("[P]recluding non-party relatives or ex-spouses from opening or operating improv-comedy-related businesses or restaurants violates CBPC [section] 16600 . . . By restricting non-party relatives and ex-spouses from engaging in a lawful business, the injunctions, with respect to those persons exceed the arbitrator's authority.").

247. "A judicial standard for deciding whether to invalidate the whole contract or only the offending words. Under this standard, only the offending words are invalidated if it would be possible to delete them simply by running a blue pencil through them, as opposed to changing, adding, or rearranging words." BLACK'S LAW DICTIONARY 196 (9th ed. 2009).

248. Comedy Club, 553 F.3d at 1287-88.

249. See supra Part III.B.2.

250. 9 U.S.C. $\S 11(c)$. 
court simply limited the scope of the covenant to counties where Comedy Club, Inc.'s improv clubs currently operate. ${ }^{251}$

These actions by the Ninth Circuit in Comedy Club perfectly illustrate a court's ability "to effect the intent thereof and promote justice between the parties" "[w]here the award is imperfect in matter of form not affecting the merits of the controversy."252 By simply approaching these edits as modifications to an otherwise unenforceable arbitral award, the Ninth Circuit would have refrained from performing a de novo merits review and avoided characterizing the award as an excess of authority. To the extent that an aggrieved party-against whom a court modifies an awarddisagrees with a modification, the party still has full access to the appellate process of the courts. ${ }^{253}$ Once illustrated, the reconceptualization's utility becomes readily apparent, replacing the ambiguity of manifest disregard with a straight-forward standard of review under the FAA. At the same time, the analysis promotes rather than compromises arbitral finality by confining judicial review to the award only, thereby protecting and maintaining the integrity of arbitration's benefit of the bargain.

\section{CONCLUSION}

Since the U.S. Supreme Court decided Hall Street in 2008, the lower courts have grappled with the Court's assertion about the exclusivity of FAA sections 10 and 11 for vacatur and modification of arbitral awards. When coupled with the Court's apparent uneasiness with the foundation of manifest disregard in Wilko, circuit courts have split over the continued validity of manifest disregard as ground for vacatur. However, one thing is clear: based on the history and ambiguity inherent in the manifest disregard doctrine, any remnant of the doctrine serves to frustrate one of the critical benefits of the arbitration bargain: finality.

With the current split among the circuit courts, the state of the law of manifest disregard remains suspended, awaiting a conclusive declaration from the Supreme Court. When the Court makes this decision, by reconceptualizing a "final" award under FAA section 10(a)(4) and allowing an increased power to modify for enforceability under section 11(c), the Court can provide a tool to lower courts that will allow them to have some

251. Comedy Club, 553 F.3d at 1293.

252. 9 U.S.C. $\S 11$.

253. Indeed, Julius Henry Cohen trumpeted this point in his description of the new federal arbitration process: "When the award has been entered as a judgment, of course, an appeal may be taken as from an ordinary judgment in an action, and similarly an appeal may be taken from an order vacating, modifying, or correcting the award though the statute does not specifically prescribe this." Cohen \& Dayton, supra note 20, at 273. 
Brown: "Final" Awards Reconceptualized: A Proposal to Resolve the Hall S

[Vol. 13: 325, 2013]

PEPPERDINE DISPUTE RESOLUTION LAW JOURNAL

semblance of supervision over arbitral awards while leaving the merits of the awards undisturbed. When parties contract for arbitration, they agree on a gamble. However, not all gambles pay off, and the FAA already safeguards the procedural fairness required to maintain the integrity of arbitration proceedings. By reconceptualizing the traditional notion of finality, courts will put their supervisory tools to better use. 